\title{
Synthesis and determination of the absolute configuration of Fudecalone
}

\author{
Hidenori Watanabe, ${ }^{a} *$ Takahiro Yamaguchi, ${ }^{\text {a }}$ Takeshi Furuuchi, ${ }^{\text {a }}$ Masaru Kido, \\ Masahiko Bando, ${ }^{b}$ and Takeshi Kitahara ${ }^{a}{ }^{a}$ \\ ${ }^{a}$ Department of Applied Biological Chemistry, Graduate School of Agricultural and Life \\ Sciences, The University of Tokyo, 1-1-1 Yayoi, Bunkyo-ku, Tokyo 113-8657, Japan \\ ${ }^{b}$ Otsuka Pharmaceutical Co., Ltd., 463-10 Kagasuno, Kawauchi-cho, Tokusima-city 771-0192, \\ Japan \\ E-Mail: ashten@mail.ecc.u-tokyo.ac.jp
}

Dedicated to Professor Keiichiro Fukumoto on his $70^{\text {th }}$ birthday

(received 01 Aug 03; accepted 02 Nov 03; published on the web 25 Nov 03)

\begin{abstract}
We have synthesized the proposed structure of Fudecalone, but its NMR spectral data were not identical with those of the natural compound. Further investigations on the conformational isomerization and synthesis of a diastereomer show natural fudecalone to be a trans-fused octalone. The absolute configuration has been determined following the synthesis of both enantiomers.
\end{abstract}

Keywords: Fudecalone, anticoccidial, Penicillium sp. FO-2030, Eimeria tenella

\section{Introduction}

In 1995, Omura and his coworkers isolated and identified a new drimane sesquiterpene, fudecalone, 1, from a culture broth of Penicillium sp. FO-2030. ${ }^{1}$ It exhibited anticoccidial activity against monensin-resistant Eimeria tenella at concentrations of more than $16 \mu M$. The structure was elucidated mainly by NMR, and the conformation was reported to be 1a, as shown in Fig. 1. As outlined in our preliminary communications, ${ }^{2,3}$ synthetic 1 was not identical with natural fudecalone, and we have found that the correct structure is 2 . In this paper, we describe details of the synthesis of $\mathbf{1}$ and $\mathbf{2}$. We also record the synthesis of both enantiomers of $\mathbf{2}$, which enables us to clarify the absolute configuration of fudecalone. 


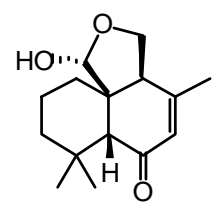

1

proposed structure of fudecalone

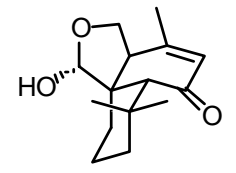

$1 a$

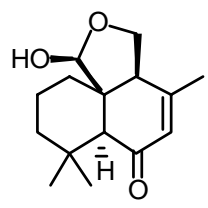

2

fudecalone

\section{Figure 1}

\section{Results and Discussion}

First, to synthesize the proposed cis-fused structure of fudecalone, we planned the retrosynthetic strategy shown in Scheme 1. We thought fudecalone 1 would be obtained by reduction of a keto lactone 3, which was prepared by the cationic cyclization of an enol ether $\mathbf{4}$. The compound 4 might be obtained by Birch reduction of the known phthalide $\mathbf{6}^{4}$ followed by alkylation of the resulting lactone enolate with the homoprenyl halide 5.

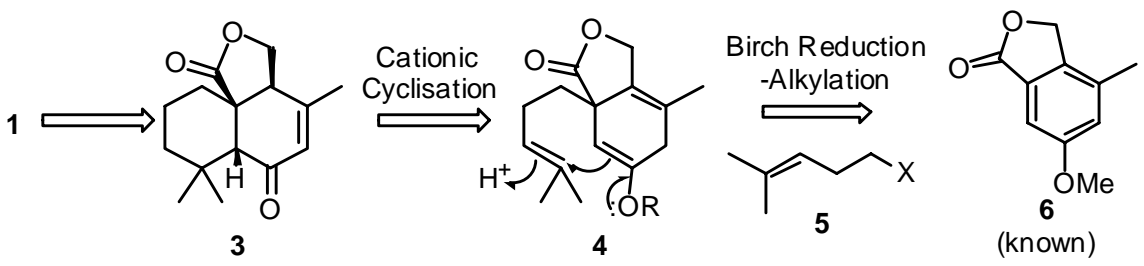

\section{Scheme 1}

We started our synthesis from the known phthalide 6. ${ }^{4}$ However, the reported procedure was lengthy and complicated, and we developed a simpler method for multi-gram preparation of $\mathbf{6}$, as shown in Scheme 2. Diels-Alder reaction of the known pyrone 7 with dimethyl acetylenedicarboxylate followed by decarboxylation gave the aromatic diester $\mathbf{8 a}{ }^{5}$ For the regioselective reduction of one of the two ester carbonyls, $8 \mathbf{a}$ was converted into the half-esters, 8b and 8c. However, disappointingly, all our attempts at reduction $\left(\mathrm{LiBH}_{4}\right.$ or DIBAL for $\mathbf{8 b}$, $\mathrm{BH}_{3}$ for 8c were unsuccessful, probably owing to the electron-donating effect of the methoxy group at the para position. We then decided to take advantage of the electronic effect of this group. Both ester groups of $\mathbf{8 a}$ were reduced to the diol 9, whose treatment with conc. $\mathrm{HCl}$ in ether at $0{ }^{\circ} \mathrm{C}$ gave the chloro-alcohol 10 regioselectively. Jones' oxidation and then base treatment caused lactone formation to afford $\mathbf{6}$ in 63\% yield over five steps from 7. 


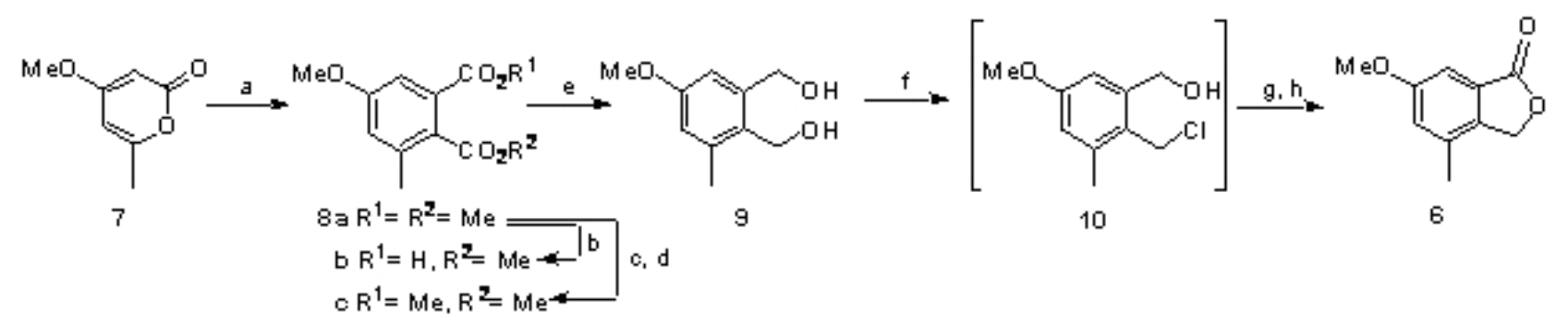

a) Dimethyl acetylenedicarboxylate, $\left.180.200^{\circ} \mathrm{C}(89 \%) \mathrm{b}\right) \mathrm{LiOH}(1 \mathrm{eq}), \mathrm{Hz} \mathrm{O}, \mathrm{MeOH}, \mathrm{THF}, 40-45^{\circ} \mathrm{C}(90 \%)$

c) $\mathrm{LiOH}, \mathrm{H}_{2} \mathrm{O}$, MeOH, THF , $60^{\circ} \mathrm{C}(94 \%)$; d) $\mathrm{Ac} 2 \mathrm{O} ; \mathrm{MeOH}, 45^{\circ} \mathrm{C}(95 \%)$ e) $\mathrm{LiAlH}_{\mathbf{l}}$. THF (99\%); f) co nc. HCl,

E $0,0^{\circ} \mathrm{C}$; g) Jones' reagent, acetone; h) aq. $\mathrm{NaOH}$, THF ( $72 \%$ in 3 steps).

\section{Scheme 2}

Birch reduction of $\mathbf{6}$ with potassium in liquid ammonia, followed by alkylation of the resulting enolate with the iodide $\mathbf{1 1}^{6}$ gave 12 in 62\% yield (Scheme 3). Acid hydrolysis of the methyl enol ether and isomerization of the double bond afforded the conjugate enone 13 (46\%), which was converted into an enol acetate 14 with LDA and acetic anhydride. When the compound 14 was treated with $\mathrm{BF}$ gas in wet $\mathrm{CH}_{2} \mathrm{Cl}_{2}$, an axial attack of a cationic side chain to enol acetate took place and the desired cis-octalone 3 was obtained as the sole product, in excellent yield (90\%). On the other hand, direct cyclization of 12 under various conditions was unsuccessful. The stereochemistry, including the conformation, was confirmed by X-ray analysis. For converting 2 into fudecalone, an unsaturated ketone and lactone carbonyl were reduced with DIBAL (4 equiv.) followed by selective oxidation of the resulting allylic alcohol 15 with $\mathrm{MnO}_{2}$ to give 16 as an inseparable diastereomeric mixture. Disappointingly, neither diastereomer had ${ }^{1} \mathrm{H}$ NMR identical with the natural product, although the patterns of the peaks were very similar. Further NOESY experiments of $\mathbf{1 5}$ revealed the stereochemistry to be $\mathbf{1 b}$, which is the conformational isomer of the reported structure 1a.
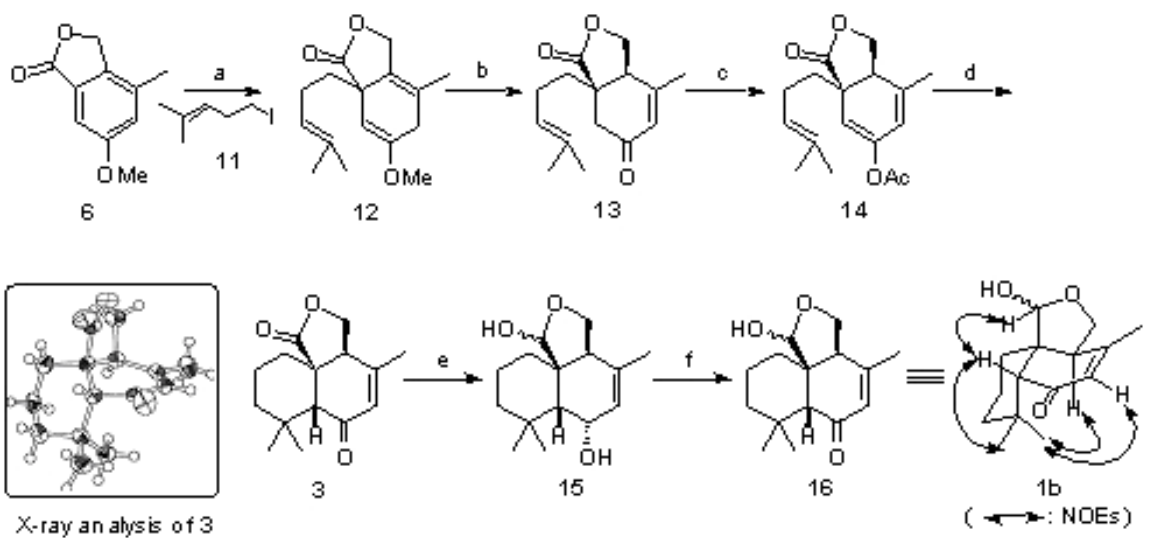

(a) K, liq. $\mathrm{NH}_{3}$, t-BuOH; Lier, 11 , THF-HMPA, $-78^{\circ} \mathrm{C}$ (62\%); (b) $3 \mathrm{~N} \mathrm{HCl}$, THF (46\%); (c) LDA, THF; Ac2O, $-78^{\circ} \mathrm{C}$ (84\%): (d) $\mathrm{BF}_{3}$ gas, $\mathrm{CH}_{2} \mathrm{Cl}_{2}-\mathrm{H}_{2} \mathrm{O}$ (90\%); (e) DIBAL (4 eq), $\mathrm{CH}_{2} \mathrm{Cl}_{2},-78^{\circ} \mathrm{C}$ (91\%); (t) $\mathrm{MnO}_{2}, \mathrm{CH}_{2} \mathrm{Cl}$. (84\%).

\section{Scheme 3}


According to MM3 calculations, the steric energy for $\mathbf{1 b}$ is more stable by $2.1 \mathrm{kcal} / \mathrm{mol}$ than for 1a, and we thought it interesting that the unstable conformer might be produced in the biogenetic process and can exist as a natural product because of the extra-high energy barrier between 1a and 1b. We therefore investigated the conformational isomerization from $\mathbf{1 b}$ to $\mathbf{1 a}$.

We have reported previously, ${ }^{3}$ that the intermediate 2 was converted in seven steps into the selenide 17, which had the same conformation as 1a (Scheme 4). However, when the selenide was eliminated by oxidation with $\mathrm{m}$-CPBA, the conformation of the obtained enone 18 has changed to the previous $\mathbf{1 b}$ type again, which was confirmed by X-ray analysis. From these results, we concluded that the energy barrier between 1a and $\mathbf{1 b}$ was not so high and that the proposed relative stereochemistry was incorrect, and so we attempted to synthesize the diastereomers.
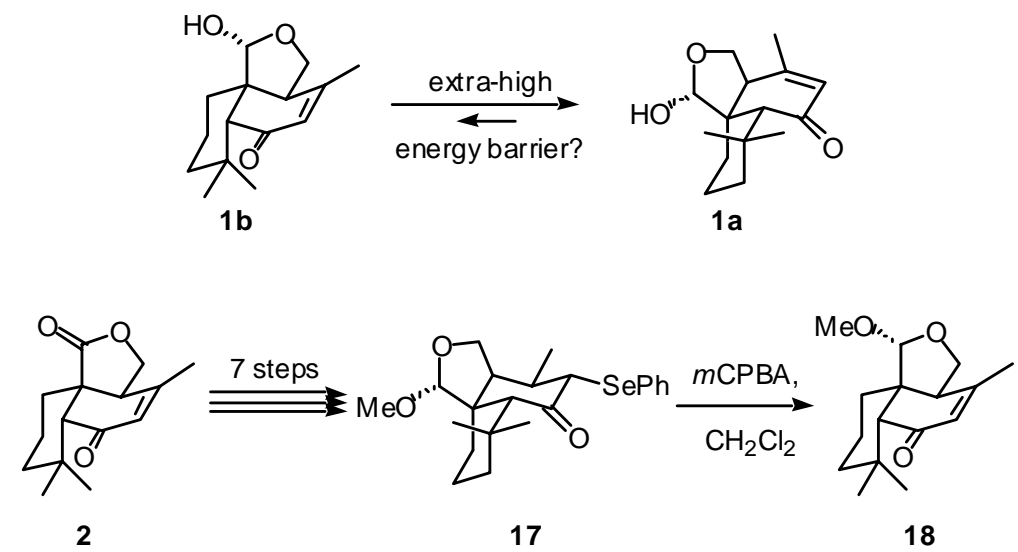

\section{Scheme 4}

We supposed two types of possible diastereomers; the trans-octalone $\mathbf{1 9}$ and the trans-lactol 20 (Figure 2). As most drimane sesquiterpenoids have a trans-fused decalin skeleton, we preferred the trans-octalone $\mathbf{1 9}$ as the next target. The previous intermediate $\mathbf{3}$ was treated with various bases to isomerize it from the cis-fused octalone to the trans-isomer (Scheme 5). However, treatment with organic bases resulted only in a recovery or a decomposition of $\mathbf{3}$, and aq. $\mathrm{NaOH}$ gave an eliminated product 22. To avoid elimination, we then investigated the epimerization, after hydrogenation of the double bond.

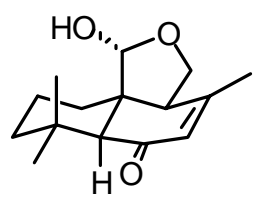

19

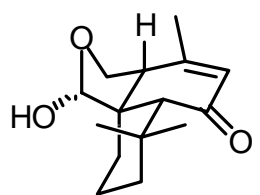

20

\section{Figure 2}




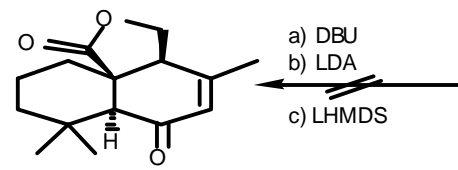

21

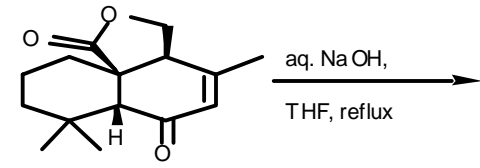

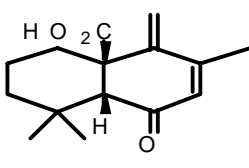

22

\section{Scheme 5}

The enone 3 was hydrogenated with $\mathrm{Pd}-\mathrm{C}$ to afford a ketone 23 as almost a single isomer (Scheme 6). This direct hydrogenation made the methyl group of $23 \alpha$-oriented, because the $\alpha$ face of the olefin is sterically congested by the axial 7-methyl group. Treatment of 23 with aq. $\mathrm{LiOH}$ and re-lactonization of the resulting hydroxy acid, by refluxing with PPTS in benzene for 4 hours gave 26 in $69 \%$ yield over two steps. Interestingly, when the trans-ketone 26 was treated with PPTS for a longer time, it was completely isomerized into the cis-ketone 23. On the other hand, when cis-ketone $\mathbf{2 3}$ was treated under the same conditions, or with DBU under reflux in THF, it was not converted into the trans-ketone 26. The lactone-opening was therefore essential for the isomerization from cis-23 to trans-26 via 24 and 25. These results were supported by MM3 calculations. The steric energy of cis-23 is $1.7 \mathrm{kcal} / \mathrm{mol}$ more stable than that of trans-26, and trans-25 was estimated to be $1.9 \mathrm{kcal} / \mathrm{mol}$ more stable than cis-24.

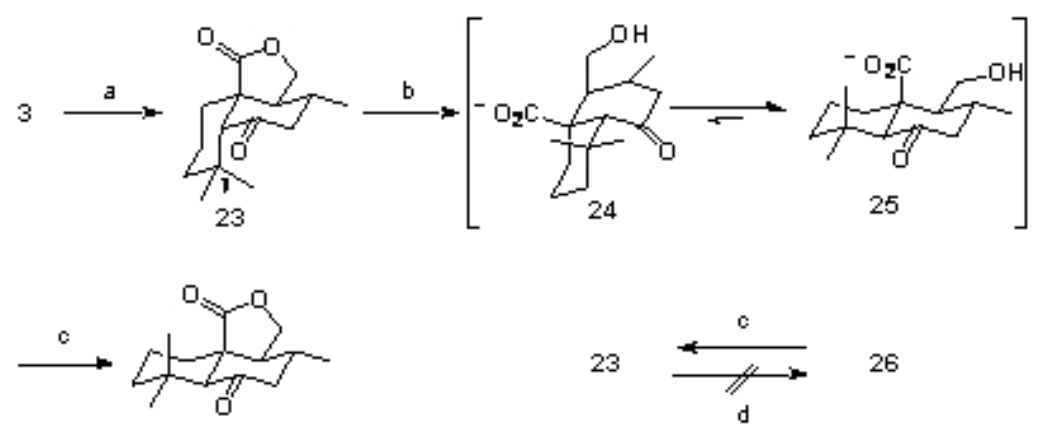

26

(a) $\mathrm{H}_{2}, \mathrm{Pd} \mathrm{C}, \mathrm{EtOH}$, it (88\%); (b) a q. LiOH, THF, reflux; (c) PPTS, benzene, r eflux (69\% in two steps, $92 \%$ bas ed on recovere 23 ); (d) DBU, THF, reflux.

\section{Scheme 6}

The enolate derived from 26 by LDA treatment was trapped with TMSCl to give the silyl enol ether 27. Treatment of $\mathbf{2 7}$ with NBS gave the bromide 28, then dehydrobromination with DBU afforded an enone $\mathbf{2 1}$ in 79\% overall yield, and the stereochemistry of $\mathbf{2 1}$ was confirmed by $\mathrm{X}$-ray analysis (Scheme 7). The unsaturated ketone and the lactone carbonyl of 21 were reduced with DIBAL (4 eq.), and the resultant allylic alcohol was re-oxidized with $\mathrm{MnO}_{2}$ to furnish $( \pm$ )-2 in $56 \%$ yield over two steps. In this case, the lactol was obtained as a single isomer and the stereochemistry of its $\mathrm{OH}$ group was determined to be $S^{*}$ by NOE experiment. The ${ }^{1} \mathrm{H}$ and ${ }^{13} \mathrm{C}$ 
NMR spectroscopic data of $( \pm)-2$ showed complete accordance with those of natural fudecalone, except for the NOE data. ${ }^{3}$

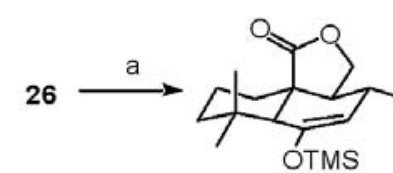

27

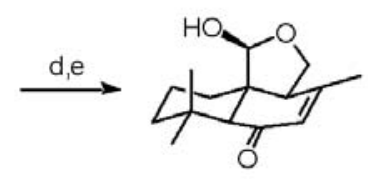

$( \pm)-2$

identical with natural Fudecalone

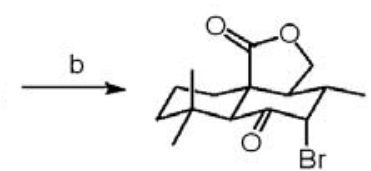

28

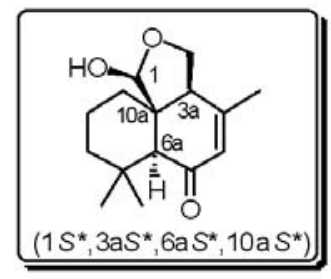

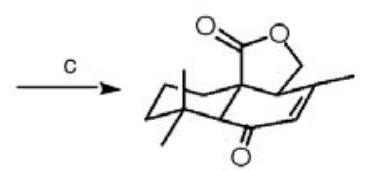

21

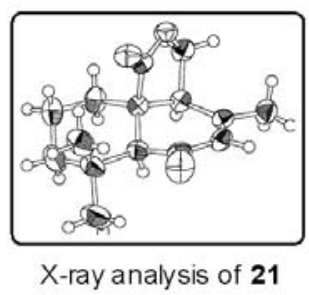

(a) LDA, THF; TMSCI, Et 3 N, $-78^{\circ} \mathrm{C}(91 \%)$; (b) NBS, THF, rt (83\%); (c) DBU, THF, reflux (93\%);

(d) DIBAL, tol. $-\mathrm{CH}_{2} \mathrm{Cl}_{2}-78^{\circ} \mathrm{C}$; (e) $\mathrm{MnO}_{2}, \mathrm{CH}_{2} \mathrm{Cl}_{2}$, it (56\% in two steps).

\section{Scheme 7}

The NOESY spectrum of our $( \pm)-2$ showed slight differences from the reported data, as illustrated in Figure 3. NOEs of $( \pm)-2$ between $\mathrm{H}-6 \mathrm{a}$ and each of $\mathrm{H}-3 \mathrm{a}$ and $\mathrm{H}-10_{\mathrm{ax}}$ indicated that C-6a had the $S^{*}$ configuration, and NOEs between H-1 and each of $\mathrm{H}-9_{\text {ax }}$ and $\mathrm{H}-10_{\text {eq }}$ indicated that C-1 also had the $S^{*}$ configuration. On the other hand, NOEs between H-6a and each of H-1 and $\mathrm{H}_{3}-13$ of $1 \mathrm{a}$ indicated by dashed arrows, which were the decisive factor in determining fudecalone to be 1a, ${ }^{1}$ were hardly observed. From these points of view, the relative configuration of fudecalone was determined to be $1 S^{*}, 3 a S^{*}, 6 a S^{*}, 10 a S^{*}$.

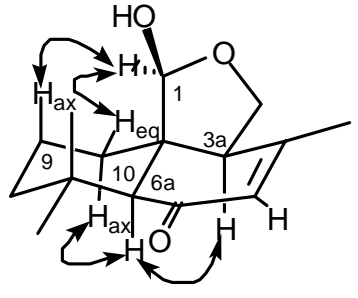

Synthetic ( \pm )-2

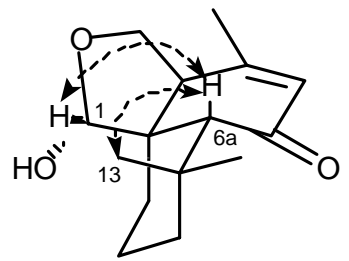

Proposed 1a

\section{Figure 3}

To determine the absolute configuration, we next started a synthesis of optically active fudecalone. The racemic enone of 21 was reduced with $\mathrm{NaBH}_{4}$ and $\mathrm{CeCl}_{3}$ to give the allylic alcohol 29, which was converted into a diastereomeric mixture of camphanates. Two 
diastereomers were easily separated by silica-gel column chromatography to afford the (+)- and (-)-camphanates, 30 and 31, in 49\% and 46\% yields, respectively. Methanolysis of 30 gave (-)29 and the absolute configuration was determined at this stage by a modified Mosher's method ${ }^{8}$ after converting (-)-29 into the corresponding $(R)$ - and $(S)$-MTPA esters 33 and comparing their chemical shifts in ${ }^{1} \mathrm{H}$ NMR (Scheme 8). The lactone of (-)-29 was then reduced with DIBAL and selective oxidation of the allylic alcohol (+)-32 with $\mathrm{MnO}_{2}$ afforded (+)-fudecalone [(+)-2]. Similarly, 31 was converted into (-)-2 in 72\% yield over three steps. Although the optical rotations and melting points of our synthetic (+)- and (-)-2 did not agree with those reported, we concluded that the natural fudecalone was $(+)-2$ from the positive rotation.

In conclusion, we have synthesized the proposed structure of fudecalone $\mathbf{1 b}$, which was found to be a conformational isomer of the proposed structure 1a. Although our investigations of the conformational isomerization from $\mathbf{1 b}$ to $\mathbf{1 a}$ were fruitless, we synthesized the trans-fused octalone 2 as a racemate and found that it showed identical NMR spectroscopic data with that of the natural fudecalone. By further NOESY experiments, we determined the correct relative configuration of fudecalone. Moreover, by optical resolution, we synthesized both enantiomers and determined the absolute configuration of the natural compound to be $1 S, 3 a S, 6 a S, 10 a S$.

Bioassays of both enantiomers and some intermediates are now in progress, and the details will be reported in due course.

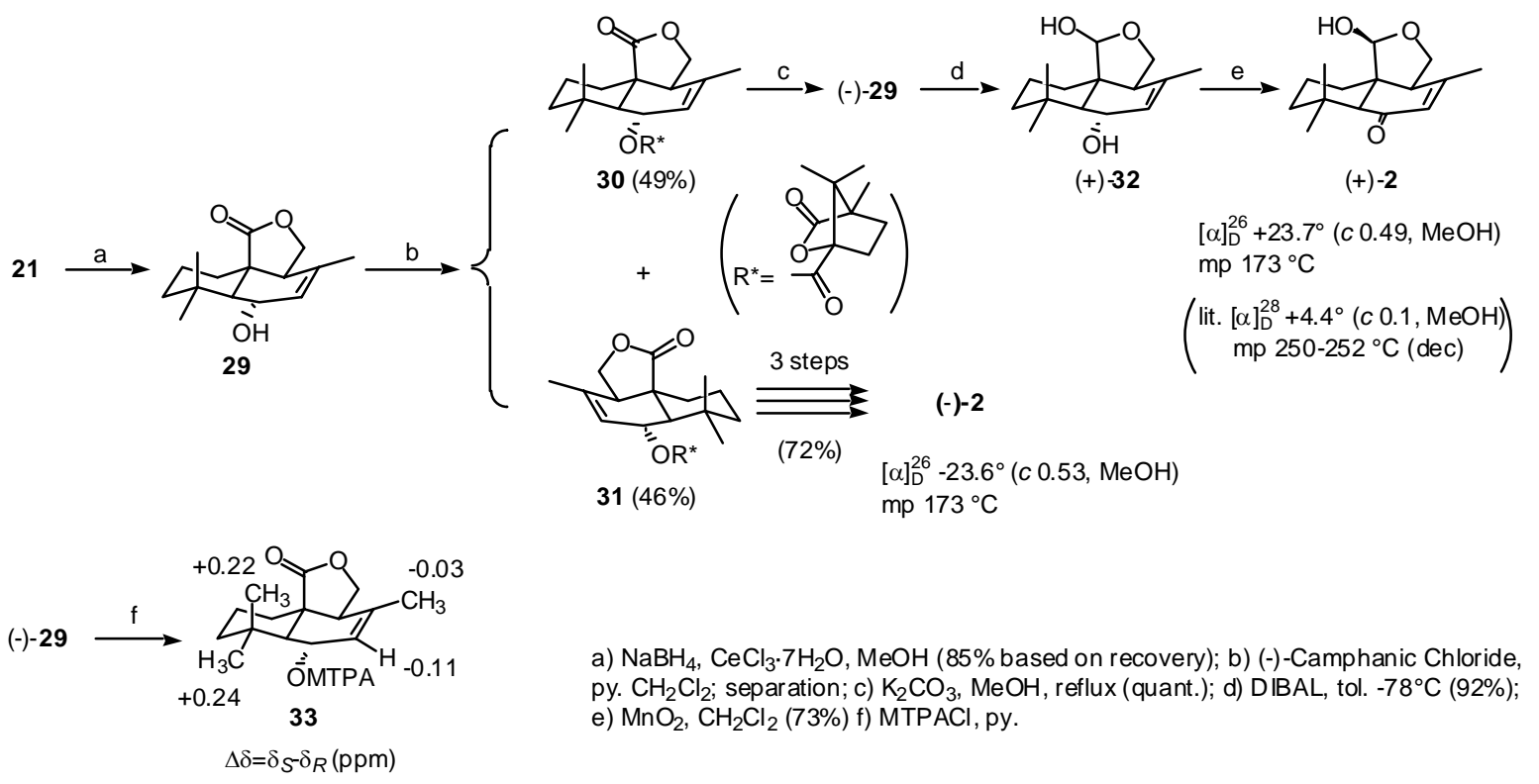

\section{Scheme 8}

\section{Experimental Section}


General Procedures. All boiling points (bp) and melting points (mp) were uncorrected. RT denotes room temperature. Infrared spectra (IR) were measured on a Jasco FT/IR-230 spectrometer. Proton and carbon-13 magnetic resonance spectra $\left({ }^{1} \mathrm{H}-\mathrm{NMR}\right.$ and $\left.{ }^{13} \mathrm{C}-\mathrm{NMR}\right)$ were recorded on a JEOL JNM-AL300 or a JEOL JMN $\alpha-500$ spectrometer. Chemical shifts are reported in ppm $(\delta)$ relative to internal chloroform $\left(\delta 7.26\right.$ for ${ }^{1} \mathrm{H}$ and $\delta 77.0$ for $\left.{ }^{13} \mathrm{C}\right)$. HR-FABMS spectra were recorded on a JEOL JMS-HX110 mass spectrometer. Optical rotations were measured on a Jasco DIP 1000 polarimeter. Melting points were measured on a Yanagimoto micro melting apparatus. Analytical thin-layer chromatography (TLC) was carried out using 0.25 mm Merck silica gel $60 \mathrm{~F}_{254}$ precoated glass-backed plates. Compounds were visualized by ultra violet light $(254 \mathrm{~nm})$, iodine vapor, or phosphomolybdic acid spray reagent. Column chromatography was performed on Merck silica gel 60 or Kanto Chemical 60 N (spherical, neutral). All solvents were reagent grade. Tetrahydrofuran (THF) and diethyl ether were freshly distilled from sodium/benzophenone under argon. Dichloromethane, benzene, and hexamethylphosphoric triamide (HMPA) were distilled from calcium hydride and stored over 4A-molecular sieves. Methanol and absolute ethanol were used without purification.

5-Methoxy-3-methylphthalic acid 2-methyl ester (8b). To a solution of the dimethyl ester 8a, $3.32 \mathrm{~g}, 13.9 \mathrm{mmol})$ in THF $(40 \mathrm{ml})$ and $\mathrm{MeOH}(1 \mathrm{ml})$ was added $\mathrm{LiOH} \cdot \mathrm{H}_{2} \mathrm{O}(651 \mathrm{mg}$, $15.5 \mathrm{mmol})$ in $\mathrm{H}_{2} \mathrm{O}(30 \mathrm{ml})$. After stirring for $16 \mathrm{~h}$ at $40-45^{\circ} \mathrm{C}$, the reaction mixture was washed with $\mathrm{Et}_{2} \mathrm{O}$ and the aqueous layer was acidified to $\mathrm{pH} 2$ by the addition of $3 \mathrm{M} \mathrm{HCl}$, and extracted with EtOAc. The organic extracts were washed with brine, dried over $\mathrm{MgSO}_{4}$ and concentrated in vacuo to afford $\mathbf{8 b}(2.82 \mathrm{~g}, 90 \%)$. ${ }^{1} \mathrm{H}$ NMR $\left(90 \mathrm{MHz}^{\mathrm{CDCl}} \mathrm{CD}_{3}\right) \delta=2.37(3 \mathrm{H}, \mathrm{s}), 3.86(3 \mathrm{H}, \mathrm{s})$, $3.90(3 \mathrm{H}, \mathrm{s}), 6.98(1 \mathrm{H}, \mathrm{d}, J=2.2 \mathrm{~Hz}), 7.40(1 \mathrm{H}, \mathrm{d}, J=2.2 \mathrm{~Hz})$.

5-Methoxy-3-methylphthalic acid. To a solution of the dimethyl ester 8a, $1.57 \mathrm{~g}, 6.59 \mathrm{mmol}$ in THF $(50 \mathrm{ml})$ and $\mathrm{MeOH}(15 \mathrm{ml})$ was added $\mathrm{LiOH} \cdot \mathrm{H}_{2} \mathrm{O}(1.57 \mathrm{~g}, 37.4 \mathrm{mmol})$ in $\mathrm{H}_{2} \mathrm{O}(40 \mathrm{ml})$. After stirring for $30 \mathrm{~h}$ at $60{ }^{\circ} \mathrm{C}$, the reaction mixture was washed with $\mathrm{Et}_{2} \mathrm{O}$ and the aqueous layer was acidified to $\mathrm{pH} 3$ with $3 \mathrm{M} \mathrm{HCl}$, saturated with $\left(\mathrm{NH}_{4}\right)_{2} \mathrm{SO}_{4}$ and extracted with EtOAc. The organic extracts were washed with brine, dried over $\mathrm{MgSO}_{4}$ and concentrated in vacuo to afford the substituted phthalic acid (94\%). ${ }^{1} \mathrm{H}$ NMR (90 $\left.\mathrm{MHz} \mathrm{CDCl}_{3}\right): \delta=2.37(3 \mathrm{H}, \mathrm{s}), 3.86(3 \mathrm{H}, \mathrm{s})$, $7.03(1 \mathrm{H}, \mathrm{d}, J=2.5 \mathrm{~Hz}), 7.27(1 \mathrm{H}, \mathrm{d}, J=2.5 \mathrm{~Hz})$.

5-Methoxy-3-methylphthalic acid 1-methyl ester (8c). Acetic anhydride (15 ml) was added to the preceding dicarboxylic acid and removed in vacuo. After repeating this procedure three times, $\mathrm{MeOH}(15 \mathrm{ml})$ was added to the residue. Stirring for $18 \mathrm{~h}$ at $45{ }^{\circ} \mathrm{C}$ followed by evaporation gave 8c (120 mg, 95\%). ${ }^{1} \mathrm{H}$ NMR $\left(90 \mathrm{MHz} \mathrm{CDCl}_{3}\right) \delta=2.48(3 \mathrm{H}, \mathrm{s}), 3.86(3 \mathrm{H}, \mathrm{s})$, $3.93(3 \mathrm{H}, \mathrm{s}), 6.93(1 \mathrm{H}, \mathrm{d}, J=2.6 \mathrm{~Hz}), 7.28(1 \mathrm{H}, \mathrm{d}, J=2.6 \mathrm{~Hz}), 8.90-10.10$ (1H, br. s).

(2-Hydroxymethyl-5-methoxy-3-methylphenyl)methanol (9). A solution of the dimethyl ester 8a, $9.43 \mathrm{~g}, 40 \mathrm{mmol})$ in THF $(50 \mathrm{ml})$ was added to the suspension of $\mathrm{LiAlH}_{4}(5.30 \mathrm{~g}, 140 \mathrm{mmol})$ in THF $(200 \mathrm{ml})$ at $0{ }^{\circ} \mathrm{C}$. After stirring for $15 \mathrm{~min}$, the reaction was quenched by dropwise addition of $\mathrm{H}_{2} \mathrm{O}(5.3 \mathrm{ml}), 15 \%$ aq. $\mathrm{NaOH}(5.3 \mathrm{ml})$, then $\mathrm{H}_{2} \mathrm{O}(16 \mathrm{ml})$. The reaction mixture was filtered through Celite and concentrated in vacuo. The residue was purified by silica gel column 
chromatography (hexane:EtOAc=2:1-1:1) to afford the diol 9 (7.16 g, 99\%) as a colorless solid. mp: 71-72 ${ }^{\circ} \mathrm{C}$. IR (KBr): $v=3271$ (br. s), 1610 (s), 1489 (s), $1321(\mathrm{~s}), 1148$ (s), 991 (s) cm ${ }^{-1} .{ }^{1} \mathrm{H}$ $\operatorname{NMR}\left(90 \mathrm{MHz} \mathrm{CDCl}_{3}\right): \delta=2.43(3 \mathrm{H}, \mathrm{s}), 3.81(3 \mathrm{H}, \mathrm{s}), 4.72(4 \mathrm{H}$, br. d, $J=4.0 \mathrm{~Hz}), 6.74(2 \mathrm{H}$, br. s). $\left.{ }^{13} \mathrm{C} \mathrm{NMR} \mathrm{(75} \mathrm{MHz} \mathrm{CDCl}_{3}\right) \delta=19.6,55.1,58.1,64.2,112.7,115.4,130.0,139.6,114.5$, 158.7. Anal. Calcd for $\mathrm{C}_{10} \mathrm{H}_{14} \mathrm{O}_{3}$ : C, 65.91; H, 7.74. Found: C, 66.14; H, 7.83\%.

6-Methyl-4-methyl-3H-isobenzofuran-1-one (6). To a solution of the diol 9, 39.5 g, $217 \mathrm{mmol}$ was added concentrated $\mathrm{HCl}(36 \mathrm{ml})$ at $0{ }^{\circ} \mathrm{C}$. After stirring for $45 \mathrm{~min}$, the mixture was dried over $\mathrm{MgSO}_{4}$ and concentrated in vacuo to afford chloro alcohol 10. The residue was dissolved in acetone (1.5 1), and Jones reagent ( $8 \mathrm{M}$ of [O], $250 \mathrm{ml}$ ) was added dropwise at $0{ }^{\circ} \mathrm{C}$. After stirring for $15 \mathrm{~h}$ at $0{ }^{\circ} \mathrm{C}, 2$-propanol $(150 \mathrm{ml})$ was added. The reaction mixture was filtered with Celite and the filtrate was saturated with $\left(\mathrm{NH}_{4}\right)_{2} \mathrm{SO}_{4}$ and extracted with EtOAc. The organic extracts were washed with brine, dried over $\mathrm{MgSO}_{4}$, and concentrated in vacuo to afford the chlorocarboxylic acid.

To a solution of the residue in THF $(750 \mathrm{ml})$ aq. $\mathrm{NaOH}(42 \mathrm{~g}, 996 \mathrm{mmol}, 200 \mathrm{ml})$ was added dropwise at $0{ }^{\circ} \mathrm{C}$ and the mixture was stirred for $18 \mathrm{~h}$ at $\mathrm{RT}$. The mixture was acidified to $\mathrm{pH} 2$ by the addition of conc. $\mathrm{HCl}$ and the aqueous layer saturated with $\left(\mathrm{NH}_{4}\right)_{2} \mathrm{SO}_{4}$, and extracted with EtOAc. The organic extracts were washed with brine, dried over $\mathrm{MgSO}_{4}$, and concentrated in vacuo. The residue was purified by column chromatography (hexane:EtOAc=3:1-1:1) to afford the phthalide $6(27.8 \mathrm{~g}, 72 \%)$ as colorless needles. $\mathrm{mp} 105^{\circ} \mathrm{C}$. IR $(\mathrm{KBr}): v=2992(\mathrm{~m}), 1760(\mathrm{~s})$, 1626 (m), 1493 (s), 1335 (s), 1083 (s), 916 (s), 869 (s), 771 (s) cm $\left.{ }^{-1} .{ }^{1} \mathrm{H} \mathrm{NMR}(90 \mathrm{MHz} \mathrm{CDCl})_{3}\right) \delta$ $=2.32(3 \mathrm{H}, \mathrm{s}), 3.86(3 \mathrm{H}, \mathrm{s}), 5.20(2 \mathrm{H}, \mathrm{s}), 7.05(1 \mathrm{H}$, br. d, $J=2.3 \mathrm{~Hz}), 7.19(1 \mathrm{H}, \mathrm{d}, J=2.3 \mathrm{~Hz})$. ${ }^{13} \mathrm{C} \mathrm{NMR}\left(75 \mathrm{MHz} \mathrm{CDCl}_{3}\right) \delta=17.4,55.6,68.9,104.8,123.3,126.5,133.5,138.2,160.8,171.5$. Anal. Calcd for $\mathrm{C}_{10} \mathrm{H}_{10} \mathrm{O}_{3}$ : C, 67.41; H, 5.66. Found: C, 67.12; H, 5.57\%.

6-Methoxy-4-methyl-4a-(4-methylpent-3-enyl)-5,7a-dihydro-3H-isobenzofuran-1-one (12). Potassium (7.00 g, $0.17 \mathrm{~g}$ atom) was dissolved in liquid $\mathrm{NH}_{3}(100 \mathrm{ml})$ at $-78^{\circ} \mathrm{C}$ under argon atmosphere. To this was added a solution of phthalide $(12.6 \mathrm{~g}, 71 \mathrm{mmol})$ and $t$ - $\mathrm{BuOH}(7.7 \mathrm{ml}$, $78 \mathrm{mmol})$ in THF $(100 \mathrm{ml})$ and the mixture was stirred for $10 \mathrm{~min}$. After the addition of dried $\mathrm{LiBr}$ (17.5 g, $201 \mathrm{mmol}$ ) followed by stirring for $1 \mathrm{~h}, \mathrm{NH}_{3}$ was evaporated off below $-30{ }^{\circ} \mathrm{C}$ under slightly reduced pressure and THF $(100 \mathrm{ml})$ was added to the residue. A solution of the iodide 11 (19.4 g, $92 \mathrm{mmol})$ in HMPA $(37 \mathrm{ml})$ was added to the mixture at $-78^{\circ} \mathrm{C}$. After stirring for $2 \mathrm{~h}$, the reaction mixture was poured into water and extracted with $\mathrm{Et}_{2} \mathrm{O}$. The organic extracts were washed with brine, dried over $\mathrm{MgSO}_{4}$ and concentrated in vacuo. The residue was purified by column chromatography (hexane:EtOAc $=5: 1)$ to afford the enol ether $12(11.53 \mathrm{~g}, 62 \%)$ as a colorless oil. IR (film): $v=1777$ (s), 1657 (m), 1609 (w), 1441 (m), 1357 (m), 1234 (m), 1088 (m), $997(\mathrm{~m}), 800(\mathrm{w}) \mathrm{cm}^{-1} .{ }^{1} \mathrm{H}$ NMR $\left(300 \mathrm{MHz} \mathrm{CDCl}_{3}\right) \delta=1.57(3 \mathrm{H}, \mathrm{s}), 1.67(3 \mathrm{H}, \mathrm{s}), 1.74(3 \mathrm{H}$, s), 1.53-1.71 (2H, m), 1.80--2.10 (2H, m), $2.48(1 \mathrm{H}, \mathrm{d}, J=20.8 \mathrm{~Hz}), 2.89(1 \mathrm{H}, \mathrm{d}, J=20.8 \mathrm{~Hz})$, $3.62(3 \mathrm{H}, \mathrm{s}), 4.83\left(2 \mathrm{H}\right.$, br. s) $4.90(1 \mathrm{H}, \mathrm{d}, J=3.0 \mathrm{~Hz}) 5.04(1 \mathrm{H}, \mathrm{t}-\mathrm{like}, J=7.6 \mathrm{~Hz}) .{ }^{13} \mathrm{C}$ NMR $(75$

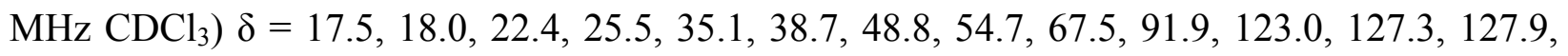
132.3, 156.6, 178.2. Anal. Calcd for $\mathrm{C}_{16} \mathrm{H}_{22} \mathrm{O}_{3}$ : C, 73.25; $\mathrm{H}, 8.45$. Found: $\mathrm{C}, 73.24 ; \mathrm{H}, 8.51 \%$. 
(3aS*,7a $\left.R^{*}\right)$-4-Methyl-7a-(4-methylpent-3-enyl)-3,3a,7,7a-tetrahydroisobenzofuran-1,6-

dione (13). To a solution of the enol ether $12(540 \mathrm{mg}, 2.06 \mathrm{mmol})$ in THF (10 ml) was added 3 $\mathrm{N} \mathrm{HCl}(8 \mathrm{ml})$ at $0{ }^{\circ} \mathrm{C}$ and the mixture was allowed to warm up to RT. After stirring for $20 \mathrm{~h}$, the reaction mixture was poured into water and extracted with EtOAc. The organic extracts were washed with satd. aq. $\mathrm{NaHCO}_{3}$ and brine, dried over $\mathrm{MgSO}_{4}$ and concentrated in vacuo. The residue was purified by silica gel column chromatography (hexane:EtOAc $=5: 1-3: 2$ ) to afford the enone 13 (234 mg, 46\%) as a colorless oil. IR (film): $v=1769$ (s), 1680 (s), 1441 (m), 1376 (m), $1297(\mathrm{~m}), 1254$ (m), 1152 (m), $1094(\mathrm{~m}), 1031(\mathrm{~m}) \mathrm{cm}^{-1} .{ }^{1} \mathrm{H}$ NMR (300 MHz CDCl 3 ) $\delta=1.57$ (3H, br. s), 1.60-1.80 (2H, m), 1.66 (3H, br. s), 1.92-2.09 (2H, m), $2.00(3 \mathrm{H}$, br. s), 2.38 (1H, d, $J=16.5 \mathrm{~Hz}), 2.67(1 \mathrm{H}, \mathrm{d}, J=16.5 \mathrm{~Hz}), 3.09(1 \mathrm{H}, \mathrm{t}, J=8.1 \mathrm{~Hz}), 4.16(1 \mathrm{H}, \mathrm{t}, J=8.4 \mathrm{~Hz}), 4.62$ $(1 \mathrm{H}, \mathrm{t}, J=8.4 \mathrm{~Hz}), 5.03(1 \mathrm{H}, \mathrm{t}-\mathrm{like}, J=6.0 \mathrm{~Hz}){ }^{13} \mathrm{C} \mathrm{NMR}\left(75 \mathrm{MHz} \mathrm{CDCl}_{3}\right) \delta=17.7,22.7,23.0$, 25.6, 35.0, 39.9, 44.1, 46.7, 68.1, 122.4, 127.6, 133.2, 155.2, 177.9 194.4. Anal. Calcd for $\mathrm{C}_{15} \mathrm{H}_{20} \mathrm{O}_{3}: \mathrm{C}, 72.55 ; \mathrm{H}, 8.12$. Found: $\mathrm{C}, 72.24 ; \mathrm{H}, 8.13 \%$.

(3a $\left.S^{*}, 7 \mathrm{a} S^{*}\right)$-7-Methyl-3a-(4-methyl-pent-3-enyl)-3-oxo-1,3,3a,7a-tetrahydroisobenzofuran-

5-yl acetate (14). To a solution of diisopropylamine $(2.1 \mathrm{ml}, 15 \mathrm{mmol})$ in THF (100 ml) was added $n$-butyl lithium $\left(9.0 \mathrm{ml}, 1.6 \mathrm{M}\right.$ in hexane) at $-78{ }^{\circ} \mathrm{C}$ under argon atmosphere. After stirring for $1 \mathrm{~h}$, a solution of $\mathbf{1 3}(2.81 \mathrm{~g}, 11.3 \mathrm{mmol})$ in THF $(25 \mathrm{ml})$ was added at $-78{ }^{\circ} \mathrm{C}$ and the mixture was stirred for $2 \mathrm{~h}$. Acetic anhydride $(2.1 \mathrm{ml}, 22 \mathrm{mmol})$ was then added and stirring was continued for $1 \mathrm{~h}$. The reaction mixture was poured into satd. aq. $\mathrm{NaHCO}_{3}$ and extracted with $\mathrm{Et}_{2} \mathrm{O}$. The organic extracts were washed with brine, dried over $\mathrm{Na}_{2} \mathrm{SO}_{4}$ and concentrated in vacuo. The residue was purified by silica gel column chromatography (hexane:EtOAc $=4: 1-2: 1$ ) to afford the dienyl acetate, $14,(2.77 \mathrm{~g}, 84 \%)$ as a colorless oil. IR (film): $v=1768(\mathrm{~s}), 1668(\mathrm{~m})$, 1617 (w), 1443 (m), 1369 (m), 1193 (s), 1119 (m), 1022 (m), 939 (w), 903 (m), 837 (w) cm ${ }^{-1} .{ }^{1} \mathrm{H}$ NMR (300 MHz CDCl $) \delta=1.41-1.94(3 \mathrm{H}, \mathrm{m}), 1.57(3 \mathrm{H}, \mathrm{s}), 1.65(3 \mathrm{H}, \mathrm{s}), 1.88(3 \mathrm{H}$, br. s), 2.06 $(1 \mathrm{H}, \mathrm{m}), 2.16(3 \mathrm{H}, \mathrm{s}), 2.90(1 \mathrm{H}, \mathrm{t}-\mathrm{like}, J=9.3 \mathrm{~Hz}), 3.86(1 \mathrm{H}, \mathrm{dd}, J=8.4,10.5 \mathrm{~Hz}), 4.54(1 \mathrm{H}, \mathrm{t}, J$ $=8.4 \mathrm{~Hz}), 5.00(1 \mathrm{H}, \mathrm{s}) 5.03\left(1 \mathrm{H}\right.$, br. s), $5.64\left(1 \mathrm{H}\right.$, br. s). ${ }^{13} \mathrm{C} \mathrm{NMR}\left(75 \mathrm{MHz} \mathrm{CDCl}_{3}\right) \delta=17.6$, 20.8, 22.0, 22.1, 25.6, 37.0, 44.8, 48.8, 70.6, 106.7, 118.8, 123.3, 132.5, 136.5, 146.6, 168.8, 179.4. Anal. Calcd for $\mathrm{C}_{17} \mathrm{H}_{22} \mathrm{O}_{4}$ : C, 70.32; H, 7.64. Found: C, 70.34; H, 7.65\%.

$\left(3 a S^{*}, 6 a R^{*}, 10 \mathrm{a} S^{*}\right)-3,3 \mathrm{a}, 6,6 \mathrm{a}, 7,8,9,10-O c t a h y d r o-4,7,7-t r i m e t h y l-1 H$-naphtho[1,8a-c]furan1,6-dione (3). Into a solution of the acetate $14(182 \mathrm{mg}, 0.63 \mathrm{mmol})$ in $\mathrm{CH}_{2} \mathrm{Cl}_{2}(180 \mathrm{ml}$, containing $22 \mu \mathrm{l}$ of $\mathrm{H}_{2} \mathrm{O}$ ) was bubbled boron trifluoride gas for $4 \mathrm{~min}$, then the reaction was quenched by the addition of satd. aq. $\mathrm{NaHCO}_{3}$. The organic layer was washed with brine, dried over $\mathrm{MgSO}_{4}$ and concentrated in vacuo. The residue was purified by silica gel column chromatography (hexane:EtOAc=2:1) to afford keto lactone $3(140 \mathrm{mg}, 90 \%)$ as colorless needles, mp: 200.5-201.5 ${ }^{\circ} \mathrm{C}$. IR (KBr): $v=1766$ (s), 1658 (s), 1469 (m), 1371 (s), 1265 (m), 1185 (s), 1139 (m), 1099 (m), 1017 (m), 970 (m), $894(\mathrm{~m}), 863$ (w), 730 (w) cm ${ }^{-1} .{ }^{1} \mathrm{H}$ NMR (500 $\left.\mathrm{MHz} \mathrm{CDCl}_{3}\right) \delta=0.77(3 \mathrm{H}, \mathrm{s}), 1.07(3 \mathrm{H}, \mathrm{s}) 1.41(1 \mathrm{H}, \mathrm{dt}, J=4.9,13.6 \mathrm{~Hz}), 1.44(1 \mathrm{H}, \mathrm{dt}, J=4.9$, $13.8 \mathrm{~Hz}), 1.51(1 \mathrm{H}, \mathrm{ddt}, J=1.7,2.9,13.3 \mathrm{~Hz}), 1.59(1 \mathrm{H}, \mathrm{m}), 1.71(1 \mathrm{H}, \mathrm{dq}, J=4.6,13.8 \mathrm{~Hz})$, $1.96(1 \mathrm{H}, \mathrm{ddt}, J=1.5,2.9,12.6 \mathrm{~Hz}), 2.03(3 \mathrm{H}, \mathrm{s}), 2.61,(1 \mathrm{H}, \mathrm{s}), 3.07(1 \mathrm{H}, \mathrm{d}, J=6.5 \mathrm{~Hz}), 4.33$ $(1 \mathrm{H}, \mathrm{d}, J=10.2 \mathrm{~Hz}), 4.48(1 \mathrm{H}, \mathrm{dd}, J=6.5,10.2 \mathrm{~Hz}), 6.02(1 \mathrm{H}, \mathrm{s}) .{ }^{13} \mathrm{C} \mathrm{NMR}\left(75 \mathrm{MHz} \mathrm{CDCl}_{3}\right) \delta$ 
$=18.6,21.6,23.2,30.1,31.2,32.9,40.5,44.3,45.7,54.4,67.3,130.9,155.0,179.4$, 197.2. Anal. Calcd for $\mathrm{C}_{15} \mathrm{H}_{20} \mathrm{O}_{3}$ : C, 72.55; H, 8.12. Found: C, 72.51; H, 8.10\%.

$\left(3 \mathrm{a} S^{*}, 6 S^{*}, 6 \mathrm{a} R^{*}, 10 \mathrm{a} S^{*}\right)-3,3 \mathrm{a}, 6,6 \mathrm{a}, 7,8,9,10-O c t a h y d r o-4,7,7-t r i m e t h y l-1 H$-naphtho[1,8ac]furan-1,6-diol (15). To a solution of the keto lactone $3(240.0 \mathrm{mg}, 0.97 \mathrm{mmol})$ in $\mathrm{CH}_{2} \mathrm{Cl}_{2}$ $(140 \mathrm{ml})$ was added DIBAL $\left(3.83 \mathrm{ml}, 1.0 \mathrm{M}\right.$ in toluene) at $-78^{\circ} \mathrm{C}$ under argon. After stirring for $1.5 \mathrm{~h}, \mathrm{MeOH}(10 \mathrm{ml})$ and Celite $(20 \mathrm{~g})$ were added successively and the mixture was stirred for $1 \mathrm{~h}$ at RT. After filtration, the solvents were removed in vacuo and the residue purified by silica gel column chromatography (hexane:EtOAc=15:1) to afford $15(221.0 \mathrm{mg}, 91 \%)$ as an inseparable mixture.

Major component. ${ }^{1} \mathrm{H}$ NMR $\left(300 \mathrm{MHz} \mathrm{CDCl}_{3}\right) \delta=0.94-1.27(2 \mathrm{H}, \mathrm{m}), 1.00(3 \mathrm{H}, \mathrm{s}), 1.13(3 \mathrm{H}$, s) $1.49-1.68(3 \mathrm{H}, \mathrm{m}), 1.67(3 \mathrm{H}, \mathrm{s}), 1.89(1 \mathrm{H}, \mathrm{m}), 2.11(1 \mathrm{H}, \mathrm{d}, J=2.7 \mathrm{~Hz}), 2.40(1 \mathrm{H}, \mathrm{t}, J=9.0$ $\mathrm{Hz}), 3.85(1 \mathrm{H}, \mathrm{t}, J=9.0 \mathrm{~Hz}), 4.14(1 \mathrm{H}, \mathrm{t}, J=9.0 \mathrm{~Hz}), 4.50(1 \mathrm{H}, \mathrm{m}), 5.36(1 \mathrm{H}, \mathrm{s}), 5.81(1 \mathrm{H}, \mathrm{m})$. Minor component. ${ }^{1} \mathrm{H}$ NMR $\left(300 \mathrm{MHz} \mathrm{CDCl}_{3}\right) \delta=0.94-1.27(2 \mathrm{H}, \mathrm{m}), 1.10(3 \mathrm{H}, \mathrm{s}), 1.19(3 \mathrm{H}$, s) 1.49-1.68 (3H, m), $1.63(3 \mathrm{H}, \mathrm{s}), 1.83(1 \mathrm{H}, \mathrm{m}), 2.03(1 \mathrm{H}, \mathrm{s}), 2.52(1 \mathrm{H}, \mathrm{t}, J=8.7 \mathrm{~Hz}), 3.55(1 \mathrm{H}$, t, $J=8.7 \mathrm{~Hz}), 4.26(1 \mathrm{H}, \mathrm{t}, J=8.7 \mathrm{~Hz}), 4.50(1 \mathrm{H}, \mathrm{m}), 5.53(1 \mathrm{H}, \mathrm{s}), 5.81(1 \mathrm{H}, \mathrm{m})$.

This mixture was used in the next reaction without further purification.

(3aS*, 6a $\left.R^{*}, 10 \mathrm{a} S^{*}\right)$-3,3a,6,6a,7,8,9,10-Octahydro-1-hydroxy-4,7,7-trimethyl-1H-naphtho[1,8ac]-furan-6-one (16). To a solution of $15(178.0 \mathrm{mg}, 0.71 \mathrm{mmol})$ in $\mathrm{CH}_{2} \mathrm{Cl}_{2}(20 \mathrm{ml})$ was added $\mathrm{MnO}_{2}(620 \mathrm{mg}, 7.4 \mathrm{mmol})$. After stirring at RT for $7 \mathrm{~h}$, the reaction mixture was filtered and concentrated in vacuo. The resulting residue was purified by silica gel column chromatography (hexane:EtOAc $=10: 1)$ to afford the enone $16(149.0 \mathrm{mg}, 84 \%)$ as an inseparable diastereomeric mixture, mp: $162-173{ }^{\circ} \mathrm{C}$.

Major component. ${ }^{1} \mathrm{H} \mathrm{NMR}\left(300 \mathrm{MHz}_{\mathrm{CDCl}}\right): \delta=0.76(3 \mathrm{H}, \mathrm{s}), 1.05(3 \mathrm{H}, \mathrm{s}), 1.24(1 \mathrm{H}, \mathrm{m})$, $1.30(1 \mathrm{H}, \mathrm{m}), 1.46(1 \mathrm{H}, \mathrm{m}), 1.50-1.70(2 \mathrm{H}, \mathrm{m}), 1.71(1 \mathrm{H}, \mathrm{m}), 1.91(3 \mathrm{H}, \mathrm{t}, J=1.0 \mathrm{~Hz}), 2.22(1 \mathrm{H}$, s), $2.72(1 \mathrm{H}$, br. d, $J=9.0 \mathrm{~Hz}), 4.09(1 \mathrm{H}, \mathrm{dd}, J=9.0,3.0 \mathrm{~Hz}), 4.33(1 \mathrm{H}, \mathrm{t}, J=9.0 \mathrm{~Hz}), 4.94(1 \mathrm{H}$, s), $5.90\left(1 \mathrm{H}\right.$, br. s). ${ }^{13} \mathrm{C}$ NMR $\left(75 \mathrm{MHz} \mathrm{CDCl}_{3}\right) \delta=18.2,22.3,24.6,31.3,33.4,34.7,41.5,44.1$, 48.4, 54.5, 70.0, 107.4, 128.5, 156.5, 200.8.

Minor component. ${ }^{1} \mathrm{H}$ NMR $\left(300 \mathrm{MHz} \mathrm{CDCl}_{3}\right) \delta=0.79(3 \mathrm{H}, \mathrm{s}), 1.01(3 \mathrm{H}, \mathrm{s}), 1.95(3 \mathrm{H}, \mathrm{t}, J=$ $1.0 \mathrm{~Hz}), 2.14(1 \mathrm{H}, \mathrm{s}), 2.81(1 \mathrm{H}$, br. d, $J=7.0 \mathrm{~Hz}), 3.97(1 \mathrm{H}$, br. d, $J=9.0 \mathrm{~Hz}), 4.33(1 \mathrm{H}, \mathrm{dd}, J=$ 9.0, $7.0 \mathrm{~Hz}), 4.98(1 \mathrm{H}, \mathrm{s}), 5.90\left(1 \mathrm{H}\right.$, br. s). ${ }^{13} \mathrm{C} \mathrm{NMR}\left(75 \mathrm{MHz}_{\mathrm{CDCl}}\right.$ ) $: \delta=18.4,22.0,24.1,25.9$, $31.5,33.8,41.3,46.2,46.7,55.5,68.5,102.7,128.5,158.8,201.0$.

$\left(3 \mathrm{a} S^{*}, 4 R^{*}, 6 \mathrm{a} R^{*}, 10 \mathrm{a} S^{*}\right)-3,3 \mathrm{a}, 4,5,6,6 \mathrm{a}, 7,8,9,10-D e c a h y d r o-4,7,7-t r i m e t h y l-1 H$-naphtho[1,8ac]-furan-1,6-dione (23). To a solution of the keto lactone $3(1.48 \mathrm{~g}, 6.0 \mathrm{mmol})$ in EtOH (120 ml) was added $10 \% \mathrm{Pd} / \mathrm{C}(1.68 \mathrm{~g})$. The mixture was stirred under a hydrogen atmosphere at RT for $63 \mathrm{~h}$. After filtration and concentration in vacuo, the residue was purified by recrystallization from EtOAc and the mother liquor was purified by silica gel column chromatography (hexane:EtOAc $=5: 1)$ to afford $23(1.31 \mathrm{~g}, 88 \%)$ as colorless needles, mp: $150{ }^{\circ} \mathrm{C}$. IR $(\mathrm{KBr}): v=$ 1761 (s), 1697 (s), 1463 (m), 1365 (s), 1255 (m), 1181 (s), 1140 (s), 1071 (m), 1019 (s), $962(\mathrm{~m}) \mathrm{cm}^{-1} .{ }^{1} \mathrm{H}$ NMR $\left(300 \mathrm{MHz}_{\mathrm{CDCl}}\right) \delta=1.04(3 \mathrm{H}, \mathrm{s}), 1.05(3 \mathrm{H}, \mathrm{s}), 1.14(3 \mathrm{H}, \mathrm{d}, J=6.6$ $\mathrm{Hz}), 1.32-1.42(2 \mathrm{H}, \mathrm{m}), 1.52-1.81(4 \mathrm{H}, \mathrm{m}), 2.00$ (1H, br. d, $J=14.4 \mathrm{~Hz}), 2.18(1 \mathrm{H}, \mathrm{dd}, J=3.9$, 
$10.8 \mathrm{~Hz}), 2.27(1 \mathrm{H}, \mathrm{t}, J=13.2 \mathrm{~Hz}), 2.38(1 \mathrm{H}, \mathrm{dd}, J=4.2,13.2 \mathrm{~Hz}), 2.67(1 \mathrm{H}, \mathrm{s}), 4.09(1 \mathrm{H}, \mathrm{d}, J=$ $9.3 \mathrm{~Hz}), 4.41(1 \mathrm{H}, \mathrm{dd}, J=3.9,9.3 \mathrm{~Hz}) .{ }^{13} \mathrm{C} \mathrm{NMR}\left(75 \mathrm{MHz} \mathrm{CDCl}_{3}\right) \delta=18.0,21.0,26.8,30.4$, 31.2 , 31.6, 32.9, 41.2, 43.2, 47.3, 49.0, 56.4, 69.2, 179.5, 208.6. Anal. Calcd for $\mathrm{C}_{15} \mathrm{H}_{22} \mathrm{O}_{3}$ : C, 71.97; H, 8.86. Found: C, 72.33; H, 8.86\%.

$\left(3 \mathrm{a} S^{*}, 4 R^{*}, 6 \mathrm{a} S^{*}, 10 \mathrm{a} S^{*}\right)-3,3 \mathrm{a}, 4,5,6,6 \mathrm{a}, 7,8,9,10-D e c a h y d r o-4,7,7-t r i m e t h y l-1 H$-naphtho[1,8ac]-furan-1,6-dione (26). To a solution of the cis-ketone 23 (549 mg, $2.2 \mathrm{mmol})$ in THF (10 ml) was added $4 \mathrm{M}$ aq. $\mathrm{LiOH}(10 \mathrm{ml})$ and the mixture was refluxed for $59 \mathrm{~h}$. The reaction mixture was poured into $\mathrm{Et}_{2} \mathrm{O}$ and extracted three times with $1 \mathrm{M}$ aq. $\mathrm{LiOH}$. The aqueous layer was acidified ( $\mathrm{pH}$ 1-2) with $\mathrm{HCl}$, saturated with $\left(\mathrm{NH}_{4}\right)_{2} \mathrm{SO}_{4}$, and extracted three times with $\mathrm{Et}_{2} \mathrm{O}$. The organic extracts were washed with brine, dried over $\mathrm{MgSO}_{4}$ and concentrated in vacuo. The residue $(610 \mathrm{mg})$ was dissolved in benzene $(20 \mathrm{ml})$ and refluxed with PPTS (93.2 $\mathrm{mg}$, $0.37 \mathrm{mmol})$ and molecular sieves $4 \mathrm{~A}(7.0 \mathrm{~g})$ using a Dean-Stark apparatus for $4 \mathrm{~h}$. The reaction mixture was poured into satd. aq. $\mathrm{NaHCO}_{3}$ and extracted with EtOAc. The organic extracts were washed with brine, dried over $\mathrm{MgSO}_{4}$ and concentrated in vacuo. The residue was purified by silica gel column chromatography (hexane: $\left.\mathrm{CH}_{2} \mathrm{Cl}_{2}=1: 3-0: 1\right)$ to afford 26 (379.5 mg, 69\%, 92\% based on recovery) as colorless plates, mp: $139-141{ }^{\circ} \mathrm{C}$. IR (KBr): v = 1768 (s), 1714 (s), 1457 (w), $1364(\mathrm{~m}), 1189(\mathrm{~m}), 1124(\mathrm{~m}), 1070$ (m), 1031 (m), 970 (m) cm ${ }^{-1} .{ }^{1} \mathrm{H}$ NMR (300 MHz $\left.\mathrm{CDCl}_{3}\right) \delta=1.10(1 \mathrm{H}, \mathrm{m}), 1.03(3 \mathrm{H}, \mathrm{s}), 1.18(3 \mathrm{H}, \mathrm{d}, J=6.3 \mathrm{~Hz}), 1.37-1.61(3 \mathrm{H}, \mathrm{m}), 1.48(3 \mathrm{H}, \mathrm{s})$, $1.64(1 \mathrm{H}$, br. d, $J=13.5 \mathrm{~Hz}), 1.93(1 \mathrm{H}, \mathrm{m}), 1.93(1 \mathrm{H}, \mathrm{d}, J=4.5 \mathrm{~Hz}) 2.17-2.41(3 \mathrm{H}, \mathrm{m}), 2.40$ $(1 \mathrm{H}, \mathrm{s}), 4.01(1 \mathrm{H}, \mathrm{d}, J=9.3 \mathrm{~Hz}), 4.47(1 \mathrm{H}, \mathrm{dd}, J=4.5,9.3 \mathrm{~Hz}) \cdot{ }^{13} \mathrm{C} \mathrm{NMR}\left(75 \mathrm{MHz} \mathrm{CDCl}_{3}\right) \delta=$ 18.5, 21.1, 22.0, 32.7, 32.9, 35.1, 35.9, 42.7, 49.5, 52.3, 52.4, 58.4, 68.6, 175.6, 206.8. Anal. Calcd for $\mathrm{C}_{15} \mathrm{H}_{22} \mathrm{O}_{3}$ : C, 71.97; H, 8.86. Found: C, 72.33; H, 8.84\%. Unreacted 23 (136.5 mg, $25 \%$ ) was recovered as colorless needles.

(3aS*,4S*,6aS*,10a $\left.S^{*}\right)$-3,3a,4,6a,7,8,9,10-Octahydro-4,7,7-trimethyl-6-(trimethylsilyloxy)$1 H$-naphtho[1,8a-c]furan-1-one (27). To a solution of diisopropylamine (440 $\mu 1,3.1 \mathrm{mmol})$ in THF $(20 \mathrm{ml})$ was added $n$-butyl lithium $(1.8 \mathrm{ml}, 1.6 \mathrm{M}$ in hexane, $2.9 \mathrm{mmol})$ at $-78{ }^{\circ} \mathrm{C}$ under argon. After stirring for $45 \mathrm{~min}$, a solution of 26 (490 mg, $1.96 \mathrm{mmol})$ in THF (10 ml) was added at $-78{ }^{\circ} \mathrm{C}$. After stirring for $4 \mathrm{~h}, \mathrm{TMSCl}\left(5.0 \mathrm{ml}, 1 \mathrm{M}\right.$ in THF containing $\left.1 \% \mathrm{~mol} \mathrm{Et}_{3} \mathrm{~N}\right)$ was added to the reaction mixture and stirring was continued for $0.5 \mathrm{~h}$. The reaction was quenched by the addition of satd. aq. $\mathrm{NaHCO}_{3}$ and the resulting mixture extracted with EtOAc. The organic extracts were washed with brine, dried over $\mathrm{Na}_{2} \mathrm{SO}_{4}$ and concentrated in vacuo. The residue was purified by recrystallization from hexane, and the mother liquor purified by neutral silica gel column chromatography (hexane:EtOAc=7:1) to afford 27 (total $574.9 \mathrm{mg}, 91 \%$ ) as colorless needles, mp: $127-128^{\circ} \mathrm{C}$. IR (KBr): $v=1766$ (s), 1647 (m), 1252 (s), 1233 (s), 1199 (m), 1032 (m), $884(\mathrm{~s}), 843(\mathrm{~s}) \mathrm{cm}^{-1} .{ }^{1} \mathrm{H}$ NMR $\left(300 \mathrm{MHz}_{\mathrm{CDCl}}\right) \delta=0.22(9 \mathrm{H}, \mathrm{s}), 1.07(3 \mathrm{H}, \mathrm{d}, J=7.2 \mathrm{~Hz})$, $1.16(3 \mathrm{H}, \mathrm{s}), 1.18(1 \mathrm{H}, \mathrm{m}), 1.32-1.50(3 \mathrm{H}, \mathrm{m}), 1.43(3 \mathrm{H}, \mathrm{s}), 1.71(1 \mathrm{H}, \mathrm{br} . \mathrm{t}, J=13.5 \mathrm{~Hz}), 1.80$ $(1 \mathrm{H}, \mathrm{t}, J=4.2 \mathrm{~Hz}), 2.15(1 \mathrm{H}, \mathrm{br} . \mathrm{d}, J=12.0 \mathrm{~Hz}), 2.26(1 \mathrm{H}$, br. s), $2.28(1 \mathrm{H}, \mathrm{m}), 3.93(1 \mathrm{H}, \mathrm{d}, J=$ $15.0 \mathrm{~Hz}), 4.48(1 \mathrm{H}, \mathrm{dd}, J=5.1,15.0 \mathrm{~Hz}), 4.72(1 \mathrm{H}, \mathrm{dd}, J=2.4,5.7 \mathrm{~Hz}) .{ }^{13} \mathrm{C} \mathrm{NMR}(75 \mathrm{MHz}$ 
$\left.\mathrm{CDCl}_{3}\right) \delta=0.3,18.6,23.1,33.1,34.9,35.5,35.6,44.1,47.6,51.9,53.4,73.4,106.5,152.6$, 177.5. Anal. Calcd for $\mathrm{C}_{18} \mathrm{H}_{30} \mathrm{O}_{3} \mathrm{Si}: \mathrm{C}, 67.03 ; \mathrm{H}, 9.38$. Found: $\mathrm{C}, 67.08 ; \mathrm{H}, 9.42 \%$.

(3a $\left.S^{*}, 4 S^{*}, 5 S^{*}, 6 \mathrm{a} S^{*}, 10 \mathrm{a} S^{*}\right)-3,3 \mathrm{a}, 4,5,6,6 \mathrm{a}, 7,8,9,10-D e c a h y d r o-5-b r o m o-4,7,7-t r i m e t h y l-1 H-$ naphtho[1,8a-c]furan-1,6-dione (28). To a solution of $27(629.2 \mathrm{mg}, 1.95 \mathrm{mmol})$ in THF $(20 \mathrm{ml})$ was added NBS (420.0 mg, $2.36 \mathrm{mmol})$ at $0{ }^{\circ} \mathrm{C}$ under argon. After stirring for $15 \mathrm{~min}$, the reaction mixture was diluted with $\mathrm{Et}_{2} \mathrm{O}$, washed with $5 \%$ aq. $\mathrm{Na}_{2} \mathrm{~S}_{2} \mathrm{O}_{4}$ and brine, dried over $\mathrm{MgSO}_{4}$ and concentrated in vacuo. The residue was purified by recrystallization from hexane and EtOAc (5:1), and the mother liquor was purified by silica gel column chromatography (hexane:EtOAc=5:1) to afford 28 (total $530.0 \mathrm{mg}, 83 \%$ ) as colorless needles, mp: $122-123{ }^{\circ} \mathrm{C}$. IR (KBr): v = 1777 (s), 1717 (s), 1454 (w), 1369 (m), 1194 (m), 1127 (s), 1031 (m), 1008 (w), $972(\mathrm{~m}) \mathrm{cm}^{-1} .{ }^{1} \mathrm{H}$ NMR $\left(300 \mathrm{MHz} \mathrm{CDCl}_{3}\right) \delta=1.05(3 \mathrm{H}, \mathrm{s}), 1.14-1.26(1 \mathrm{H}, \mathrm{m}), 1.20(3 \mathrm{H}, \mathrm{d}, J=$ $6.0 \mathrm{~Hz}) 1.46-1.71(4 \mathrm{H}, \mathrm{m}), 1.52(\mathrm{~s}, 3 \mathrm{H}), 2.05(1 \mathrm{H}, \mathrm{m}), 2.15(1 \mathrm{H}, \mathrm{dd}, J=4.2,11.1 \mathrm{~Hz}), 2.27(1 \mathrm{H}$, br. d, $J=12.3 \mathrm{~Hz}), 3.53(1 \mathrm{H}, \mathrm{s}), 4.04(1 \mathrm{H}, \mathrm{d}, J=9.6 \mathrm{~Hz}), 4.45(1 \mathrm{H}, \mathrm{d}, J=3.3 \mathrm{~Hz}), 4.47$ (1H, dd, $J=4.2,9.6 \mathrm{~Hz}) .{ }^{13} \mathrm{C} \mathrm{NMR}\left(75 \mathrm{MHz} \mathrm{CDCl}_{3}\right) \delta=18.2,18.6,22.3,31.8,32.2,35.3,37.5,42.4$, 48.5, 51.0, 52.6, 60.6, 66.9, 174.9, 201.2. Anal. Calcd for $\mathrm{C}_{15} \mathrm{H}_{21} \mathrm{BrO}_{3}$ : C, 54.72; H, 6.43. Found: C, 55.06; H, 6.42\%.

$\left(3 \mathrm{a} S^{*}, 6 \mathrm{a} S^{*}, 10 \mathrm{a} S^{*}\right)-3,3 a, 6,6 a, 7,8,9,10-O c t a h y d r o-4,7,7-t r i m e t h y l-1 H$-naphtho[1,8a-c]furan1,6-dione (21). To a solution of 28 (409.0 mg, $1.24 \mathrm{mmol})$ in THF (15 ml) was added DBU $(200 \mu \mathrm{l}, 1.34 \mathrm{mmol})$ at RT. After heating at reflux for $1 \mathrm{~h}$, the mixture was poured into satd. aq. $\mathrm{NH}_{4} \mathrm{Cl}$ and extracted with EtOAc. The organic extracts were washed with brine, dried over $\mathrm{MgSO}_{4}$, and concentrated in vacuo. The residue was purified by recrystallization from hexane: EtOAc (1:1), and the mother liquor purified by silica gel column chromatography (hexane:EtOAc=3:1) to afford the enone 21 (total $286.3 \mathrm{mg}, 93 \%$ ) as colorless needles, mp: 177.5-178.5 ${ }^{\circ} \mathrm{C}$. IR (KBr): $v=1764(\mathrm{~s}), 1678(\mathrm{~s}), 1434(\mathrm{w}), 1371(\mathrm{~m}), 1203(\mathrm{~m}), 1129(\mathrm{~m}), 1111$ (m), 1019 (w), 975 (w) cm $\mathrm{cm}^{-1} .{ }^{1} \mathrm{H}$ NMR $\left(300 \mathrm{MHz} \mathrm{CDCl}_{3}\right): \delta=1.16(3 \mathrm{H}, \mathrm{s}), 1.22(1 \mathrm{H}, \mathrm{br} . \mathrm{d}, J=$ $10.2 \mathrm{~Hz}), 1.44(3 \mathrm{H}, \mathrm{s}) 1.44-1.71(4 \mathrm{H}, \mathrm{m}), 1.91(3 \mathrm{H}, \mathrm{s}), 2.29(1 \mathrm{H}$, br. d, $J=12.9 \mathrm{~Hz}), 2.36(1 \mathrm{H}$, s), $2.85(1 \mathrm{H}, \mathrm{d}, J=5.7 \mathrm{~Hz}), 4.27(1 \mathrm{H}, \mathrm{d}, J=9.6 \mathrm{~Hz}), 4.51(1 \mathrm{H}, \mathrm{dd}, J=5.7,9.6 \mathrm{~Hz}), 5.91(1 \mathrm{H}, \mathrm{s})$. ${ }^{13} \mathrm{C}$ NMR $\left(75 \mathrm{MHz} \mathrm{CDCl}_{3}\right) \delta=18.2,20.6,21.8,32.3,33.5,42.9,47.5,52.9,54.7,66.1,131.4$, 151.7, 175.8, 195.1. Anal. Calcd for $\mathrm{C}_{15} \mathrm{H}_{20} \mathrm{O}_{3}$ : C, 72.55; H, 8.12. Found: C, 72.42; $\mathrm{H}, 8.13 \%$.

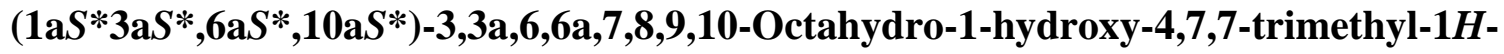

naphtho[1,8a-c]furan-6-one; $( \pm)$-Fudecalone $[( \pm)-2]$. To a solution of the enone 21 (33.0 mg, $0.13 \mathrm{mmol})$ in toluene $(4 \mathrm{ml})-\mathrm{CH}_{2} \mathrm{Cl}_{2}(2 \mathrm{ml})$ was added DIBAL $(520 \mu \mathrm{l}, 1.0 \mathrm{M}$ in toluene $)$ at $78{ }^{\circ} \mathrm{C}$ under argon. After stirring for $1 \mathrm{~h}, \mathrm{MeOH}(500 \mu \mathrm{l})$ and Celite $(5 \mathrm{~g})$ were added successively, and the mixture diluted with $\mathrm{Et}_{2} \mathrm{O}(5 \mathrm{ml})$ and stirred for $1 \mathrm{~h}$ at RT. After filtration, the solvent was removed in vacuo and the residue dissolved in $\mathrm{CH}_{2} \mathrm{Cl}_{2}(2 \mathrm{ml}) . \mathrm{MnO}_{2}(208.2 \mathrm{mg})$ was added and the resulting suspension stirred for $4 \mathrm{~h}$ at RT. After filtration, the solvent was removed in vacuo, and the residue purified by silica gel column chromatography (hexane:EtOAc $=5: 1-4: 1)$ to afford $( \pm)$-Fudecalone $[( \pm)-2]$ as a white powder $(18.7 \mathrm{mg}, 56 \%$ ), mp: $186-196{ }^{\circ} \mathrm{C}$. IR (KBr): $v=3398$ (br. s), 1673 (s), 1438 (m), 1384 (m), 1360 (m), 1092 (m), $1028(\mathrm{~m}), 984(\mathrm{~m}), 914(\mathrm{~m}), 854(\mathrm{~m}) \mathrm{cm}^{-1} .{ }^{1} \mathrm{H}$ NMR (500 MHz $\left.\mathrm{CDCl}_{3}\right) \delta=1.16(3 \mathrm{H}, \mathrm{s}), 1.24$ 
$(3 \mathrm{H}, \mathrm{s}), 1.25(1 \mathrm{H}, \mathrm{dt}, J=4.0,13.5 \mathrm{~Hz}), 1.26(1 \mathrm{H}, \mathrm{dt}, J=4.0,13.5 \mathrm{~Hz}), 1.44(1 \mathrm{H}, \mathrm{m}), 1.53(1 \mathrm{H}$, quint. d, $J=3.5,14.0 \mathrm{~Hz}), 1.63(1 \mathrm{H}, \mathrm{tq}, J=3.5,14.0 \mathrm{~Hz}), 1.82(3 \mathrm{H}, \mathrm{s}), 1.86(1 \mathrm{H}, \mathrm{m}), 2.38(1 \mathrm{H}$, s), $2.46(1 \mathrm{H}, \mathrm{d}, J=3.5 \mathrm{~Hz}), 2.61(1 \mathrm{H}, \mathrm{dd}, J=4.0,9.0 \mathrm{~Hz}), 3.96(1 \mathrm{H}, \mathrm{dd}, \mathrm{J}=4.0,9.0 \mathrm{~Hz}), 4.24$ $(1 \mathrm{H}, \mathrm{t}, J=9.0 \mathrm{~Hz}), 5.47(1 \mathrm{H}, \mathrm{d}, J=3.5 \mathrm{~Hz}), 5.82(1 \mathrm{H}, \mathrm{s}) .{ }^{13} \mathrm{C} \mathrm{NMR}\left(75 \mathrm{MHz} \mathrm{CDCl}_{3}\right) \delta=19.62$, $21.41,21.78,32.20,32.60,37.59,43.07,51.09$, 51.97, 56.53, 68.41, 100.87, 128.58, 153.11, 197.74. HR FAB MS: $m / z$ calcd for $\mathrm{C}_{15} \mathrm{H}_{23} \mathrm{O}_{3}\left[\mathrm{M}+\mathrm{H}^{+}\right] ; 251.1647$ : found; 251.1620 .

$\left(3 \mathrm{a} S^{*}, 6 S^{*}, 6 \mathrm{a} S^{*}, 10 \mathrm{a} S^{*}\right)$-3,3a,6,6a,7,8,9,10-Octahydro-6-hydroxy-4,7,7-trimethyl-1H-naphtho[1,8a-

c]furan-1-one (29). To a solution of enone 21 (96.9 $\mathrm{mg}, 0.39 \mathrm{mmol})$ in $\mathrm{MeOH}(7 \mathrm{ml})$ was added $\mathrm{CeCl}_{3} \cdot 7 \mathrm{H}_{2} \mathrm{O}(290.0 \mathrm{mg}, 1.18 \mathrm{mmol})$ and $\mathrm{NaBH}_{4}(75.8 \mathrm{mg}, 2.0 \mathrm{mmol})$ at $-20{ }^{\circ} \mathrm{C}$. After stirring for $1 \mathrm{~h}$, $\mathrm{NaBH}_{4}(120.5 \mathrm{mg}, 3.2 \mathrm{mmol})$ was added and the stirring continued for $2 \mathrm{~h}$ at $0{ }^{\circ} \mathrm{C}$. The reaction mixture was poured into brine and extracted twice with $\mathrm{Et}_{2} \mathrm{O}$. The organic extracts were dried over $\mathrm{MgSO}_{4}$ and concentrated in vacuo. The residue was purified by silica gel column chromatography (hexane: $\mathrm{CH}_{2} \mathrm{Cl}_{2}=5: 1$ ) to afford starting material (21, $58.0 \mathrm{mg}, 60 \%$ recovery) and 29 (32.8 mg, 34\%, 85\% based on recovery), colorless needles, mp: $197-199{ }^{\circ} \mathrm{C}$. IR (KBr): $v=3388$ (br. s) 1768 (s), 1444 (m), 1366 (m), 1182 (s), 1129 (s), 1098 (s), 1022 (s), 997 (s), 883 (m) cm ${ }^{-1} .{ }^{1} \mathrm{H}$ NMR (300 MHz CDCl $\left.\mathrm{M}_{3}\right) \delta=1.16-1.68$ $(5 \mathrm{H}, \mathrm{m}), 1.22(3 \mathrm{H}, \mathrm{s}), 1.35(3 \mathrm{H}, \mathrm{s}), 1.59(1 \mathrm{H}, \mathrm{d}, 10.8 \mathrm{~Hz}), 1.72(3 \mathrm{H}, \mathrm{s}), 2.19(1 \mathrm{H}, \mathrm{br} . \mathrm{d}, J=14.1$ Hz), $2.48(1 \mathrm{H}, \mathrm{d}, J=5.4 \mathrm{~Hz}), 4.15(1 \mathrm{H}, \mathrm{d}, J=9.3 \mathrm{~Hz}), 4.38(1 \mathrm{H}$, br. d, $J=14.1 \mathrm{~Hz}), 4.39(1 \mathrm{H}$, $\mathrm{dd}, J=5.4,9.3 \mathrm{~Hz}), 5.58(1 \mathrm{H}, \mathrm{s}) .{ }^{13} \mathrm{C} \mathrm{NMR}\left(75 \mathrm{MHz} \mathrm{CDCl}_{3}\right) \delta=18.0,19.9,22.6,32.8,33.4$, $36.3,43.3,47.3,51.3,52.3,67.3,68.0,131.1,133.7,177.5$. Anal. Calcd for $\mathrm{C}_{15} \mathrm{H}_{22} \mathrm{O}_{3}: \mathrm{C}, 71.97$; H, 8.86. Found: C, 71.67; H, 8.84\%.

(3aS,6S,6aS,10aS)-3,3a,6,6a,7,8,9,10-Octahydro-4,7,7-trimethyl-1-oxo-1H-naphtho[1,8ac]furan-6-yl camphanate (30) and (3aR,6R,6aR,10aR)-3,3a,6,6a,7,8,9,10-octahydro-4,7,7trimethyl-1-oxo-1H-naphtho[1,8a-c]furan-6-yl camphanate (31). To a solution of 29 (99.8 $\mathrm{mg}, 0.40 \mathrm{mmol})$ in $\mathrm{CH}_{2} \mathrm{Cl}_{2}(500 \mu \mathrm{l})$ was added pyridine $(500 \mu \mathrm{l})$ and (-)-camphanic chloride $(311.9 \mathrm{mg}, 1.44 \mathrm{mmol})$ at RT, under argon. After stirring for $15 \mathrm{~h}$, the reaction mixture was diluted with EtOAc, washed twice with satd. aq. $\mathrm{CuSO}_{4}$, twice with satd. aq. $\mathrm{NaHCO}_{3}$ and brine, and dried over $\mathrm{MgSO}_{4}$. After removal of solvent in vacuo, the residue was purified by silica gel column chromatography (hexane: $\left.\mathrm{CH}_{2} \mathrm{Cl}_{2}=5: 1-1: 1\right)$ to afford (+)-camphanate 30 (83.8 $\mathrm{mg}, 49 \%)$ and (-)-camphanate 31 (79.2 $\mathrm{mg}, 46 \%)$, both as colorless needles.

The (+)-camphanate 30. $[\alpha]_{\mathrm{D}}^{28}+20.6^{\circ}\left(\mathrm{c} 1.05, \mathrm{CHCl}_{3}\right)$. mp: $233-234{ }^{\circ} \mathrm{C}$. IR $(\mathrm{KBr}): v=1779(\mathrm{~s})$, $1764(\mathrm{~s}), 1720$ (s), 1317 (m), 1272 (m), 1171 (m), 1125 (m), $1101(\mathrm{~m}), 1063(\mathrm{~m}), 1020(\mathrm{~m}) \mathrm{cm}^{-1}$. ${ }^{1} \mathrm{H}$ NMR (300 MHz CDCl 3$) \delta=0.99(3 \mathrm{H}, \mathrm{s})$ 1.05-1.28 (2H, m), $1.10(6 \mathrm{H}, \mathrm{s}), 1.15(3 \mathrm{H}, \mathrm{s}), 1.22$ $(3 \mathrm{H}, \mathrm{s}), 1.30-1.70(4 \mathrm{H}, \mathrm{m}), 1.73(3 \mathrm{H}, \mathrm{s}), 1.84(1 \mathrm{H}, \mathrm{d}, J=11.1 \mathrm{~Hz}), 1.91(1 \mathrm{H}, \mathrm{ddd}, J=4.8,9.3$, $16.8 \mathrm{~Hz}), 2.04(1 \mathrm{H}, \mathrm{ddd}, J=4.5,9.3,13.5 \mathrm{~Hz}), 2.23(1 \mathrm{H}$, br. d, $J=13.2 \mathrm{~Hz}), 2.41$ (1H, ddd, $J$ $=4.2,10.8,13.5 \mathrm{~Hz}), 2.54(1 \mathrm{H}$, br. d, $J=5.7 \mathrm{~Hz}), 4.17(1 \mathrm{H}, \mathrm{d}, J=9.3 \mathrm{~Hz}), 4.23(1 \mathrm{H}, \mathrm{dd}, J=5.7$, $9.3 \mathrm{~Hz}), 5.43(1 \mathrm{H}, \mathrm{s}), 5.60(1 \mathrm{H}, \mathrm{d}, J=11.1 \mathrm{~Hz}) .{ }^{13} \mathrm{C} \mathrm{NMR}\left(75 \mathrm{MHz} \mathrm{CDCl}_{3}\right) \delta=9.6,16.7,16.8$, 17.9, 20.0, 22.9, 28.9, 30.6, 32.7, 33.3, 35.9, 43.0, 47.3, 47.7, 51.9, 54.4, 54.8, 67.2, 72.2, 90.7, 128.7, 133.4, 167.2, 176.7, 178.3. Anal. Calcd for $\mathrm{C}_{25} \mathrm{H}_{34} \mathrm{O}_{6}$ : C, 69.74; H, 7.96. Found: C, 69.64; H, $7.99 \%$. 
The (-)-camphanate 31. $[\alpha]_{\mathrm{D}}^{30}-36.7^{\circ}\left(\mathrm{c} 1.10 \mathrm{CHCl}_{3}\right)$. mp: $189{ }^{\circ} \mathrm{C}$. IR $(\mathrm{KBr}): v=1785(\mathrm{~s}), 1760$ (s), 1742 (s), $1447(\mathrm{w}), 1370(\mathrm{w}), 1311(\mathrm{w}), 1266(\mathrm{~m}), 1173$ (m), 1103 (m), 1063 (m), $1021(\mathrm{~m})$, $958(\mathrm{w}) \mathrm{cm}^{-1} .{ }^{1} \mathrm{H} \mathrm{NMR}\left(300 \mathrm{MHz}_{\mathrm{CDCl}}\right) \delta=0.98(3 \mathrm{H}, \mathrm{s}), 1.04-1.26(2 \mathrm{H}, \mathrm{m}), 1.09(3 \mathrm{H}, \mathrm{s}), 1.11$ $(3 \mathrm{H}, \mathrm{s}), 1.15(3 \mathrm{H}, \mathrm{s}), 1.23(3 \mathrm{H}, \mathrm{s}), 1.35-1.70(4 \mathrm{H}, \mathrm{m}), 1.73(3 \mathrm{H}, \mathrm{s}), 1.87(1 \mathrm{H}, \mathrm{d}, J=10.8 \mathrm{~Hz})$, $1.91(1 \mathrm{H}, \mathrm{m}), 2.02(1 \mathrm{H}, \mathrm{ddd}, J=4.2,8.4,17.4 \mathrm{~Hz}), 2.22(1 \mathrm{H}$, br. d, $J=13.5 \mathrm{~Hz}), 2.43(1 \mathrm{H}$, ddd, $J=4.2,10.5,13.2 \mathrm{~Hz}), 2.53(1 \mathrm{H}, \mathrm{br} . \mathrm{d}, J=4.8 \mathrm{~Hz}), 4.17(1 \mathrm{H}, \mathrm{d}, J=9.6 \mathrm{~Hz}), 4.42(1 \mathrm{H}, \mathrm{dd}, J=$ 6.0, $9.6 \mathrm{~Hz}), 5.38\left(1 \mathrm{H}\right.$, br. s), $5.63(1 \mathrm{H}, \mathrm{d}, J=10.8 \mathrm{~Hz}) .{ }^{13} \mathrm{C} \mathrm{NMR}\left(75 \mathrm{MHz} \mathrm{CDCl}_{3}\right) \delta=9.6,16.9$, 17.0, 17.8, 20.0, 22.8, 29.1, 31.1, 32.6, 33.3, 35.8, 43.0, 47.3, 47.7, 52.0, 54.5, 54.8, 67.2, 72.5, 90.7, 128.6, 133.4, 167.2, 176.7, 177.9. Anal. Calcd for $\mathrm{C}_{25} \mathrm{H}_{34} \mathrm{O}_{6}$ : C, 69.74; H, 7.96. Found: C, 69.60; H, 7.98\%.

(3aS,6S,6aS,10aS)-3,3a,6,6a,7,8,9,10-Octahydro-6-hydroxy-4,7,7-trimethyl-1H-naphtho[1,8ac]furan-1-one [(-)-29]. To a solution of the (+)-camphanate $30(68.8 \mathrm{mg}, 0.16 \mathrm{mmol})$ in $\mathrm{MeOH}$ $(20 \mathrm{ml})$ was added $\mathrm{K}_{2} \mathrm{CO}_{3}(60.0 \mathrm{mg}, 0.43 \mathrm{mmol})$. After heating at reflux for $16.5 \mathrm{~h}$, the reaction mixture was poured into water and extracted with EtOAc. The organic extracts were washed with brine, dried over $\mathrm{MgSO}_{4}$, and concentrated in vacuo. The resulting residue was purified by silica gel column chromatography (hexane:EtOAc=10:1-7:1) to afford (-)-29 (39.9 mg, quantitative yield) as colorless needles, $[\alpha]_{\mathrm{D}}^{28}-50.8^{\circ}\left(\mathrm{c} 1.03 \mathrm{CHCl}_{3}\right)$. mp: $160.5-161.5^{\circ} \mathrm{C}$. Anal. Calcd for $\mathrm{C}_{15} \mathrm{H}_{22} \mathrm{O}_{3}$ : C, 71.97; H, 8.86. Found: C, 71.91; H, 8.85\%. The IR, ${ }^{1} \mathrm{H}$ NMR, ${ }^{13} \mathrm{C}$ NMR spectra were identical with those of $( \pm)-29$

(1S,3aS,6S,6aS,10aS)-3,3a,6,6a,7,8,9,10-Octahydro-4,7,7-trimethyl-1H-naphtho[1,8a-c]furan1,6-diol [(+)-32]. To a solution of (-)-29 $(37.0 \mathrm{mg}, 0.15 \mathrm{mmol})$ in toluene $(2.5 \mathrm{ml})$ was added DIBAL (150 $\mu \mathrm{l}, 1.0 \mathrm{M}$ in toluene) at $-78{ }^{\circ} \mathrm{C}$ under argon. After stirring for $2 \mathrm{~h}$, further DIBAL (250 $\mu \mathrm{l}, 1.0 \mathrm{M}$ in toluene) was added. After stirring for $3 \mathrm{~h}, \mathrm{MeOH}(1 \mathrm{ml})$ and Celite $(5 \mathrm{~g})$ were added, the mixture diluted with $\mathrm{Et}_{2} \mathrm{O}(2 \mathrm{ml})$ and stirring continued for $1 \mathrm{~h}$ at $\mathrm{RT}$. After filtration, the solvent was removed in vacuo and the residue purified by silica gel column chromatography (hexane:EtOAc=7:1) to afford $(+)-32(34.8 \mathrm{mg}, 93 \%)$ as colorless needles, $[\alpha]_{\mathrm{D}}^{25}+39.1^{\circ}(c 1.05$ $\mathrm{CHCl}_{3}$ ). mp: $147-148{ }^{\circ} \mathrm{C}$. IR (KBr): $v=3391$ (br. s) 1743 (m), 1449 (m), 1370 (m), 1240 (m), $1115(\mathrm{~m}), 1032(\mathrm{~s}), 982(\mathrm{~s}), 916(\mathrm{~s}) \mathrm{cm}^{-1} .{ }^{1} \mathrm{H} \mathrm{NMR}\left(300 \mathrm{MHz} \mathrm{CDCl}_{3}\right) \delta=1.05(3 \mathrm{H}, \mathrm{s}), 1.13(1 \mathrm{H}$, m), $1.18(3 \mathrm{H}, \mathrm{s}), 1.25-1.69(4 \mathrm{H}, \mathrm{m}), 1.56(1 \mathrm{H}, \mathrm{d}, J=9.3 \mathrm{~Hz}), 1.71(3 \mathrm{H}, \mathrm{s}), 1.81(1 \mathrm{H}, \mathrm{br} . \mathrm{d}, J=$ $13.2 \mathrm{~Hz}), 2.29$ (1H, br. d, $J=5.4 \mathrm{~Hz}), 2.54$ (1H, br. d, $J=7.8 \mathrm{~Hz}), 3.97(1 \mathrm{H}, \mathrm{m}), 3.99(1 \mathrm{H}, \mathrm{m})$, $4.56(1 \mathrm{H}, \mathrm{d}, J=9.3 \mathrm{~Hz}), 5.34(1 \mathrm{H}, \mathrm{d}, J=6.0 \mathrm{~Hz}), 5.53(1 \mathrm{H}, \mathrm{s}) .{ }^{13} \mathrm{C} \mathrm{NMR}\left(75 \mathrm{MHz}^{\mathrm{CDCl}}\right)_{3} \delta=$ $19.5,21.3,22.8,34.0,34.8,37.4,43.3,50.5,50.7,54.7,67.0,67.5,101.7,129.5$, 135.8. HRFAB-MS: $m / z$ calcd for $\mathrm{C}_{15} \mathrm{H}_{23} \mathrm{O}_{2}\left[\left(\mathrm{M}+\mathrm{H}^{+}\right)-\mathrm{H}_{2} \mathrm{O}\right] ; 235.1698$ : found; 235.1707 .

(1S,3aS,6aS,10aS)-3,3a,6,6a,7,8,9,10-Octahydro-1-hydroxy-4,7,7-trimethyl-1H-naphtho[1,8ac]furan-6-one; (+)-Fudecalone [(+)-2]. To a solution of (+)-32 (33.2 $\mathrm{mg}, 0.13 \mathrm{mmol})$ in $\mathrm{CH}_{2} \mathrm{Cl}_{2}$ $(2 \mathrm{ml})$ was added $\mathrm{MnO}_{2}(47.8 \mathrm{mg}, 0.55 \mathrm{mmol})$. After stirring at RT for $10 \mathrm{~h}$, the mixture was filtered and concentrated in vacuo. The resulting residue was purified by silica gel column chromatography (hexane:EtOAc=5:1) to afford $(+)$-Fudecalone [(+)-26, $23.9 \mathrm{mg}, 73 \%]$ as colorless needles, $[\alpha]_{\mathrm{D}}^{26}+23.7^{\circ}(\mathrm{c} 0.49 \mathrm{MeOH}), \mathrm{mp}: 173{ }^{\circ} \mathrm{C}$. IR $(\mathrm{KBr}): v=3398$ (br. s), 1677 (s), 1439 (m), 1382 (m), 1360 (m), 1221 (m), 1155 (m), 1085 (w), 1046 (m), 1021 (m), 917 (m), 875 
(w) $\mathrm{cm}^{-1}$. Anal. Calcd for $\mathrm{C}_{15} \mathrm{H}_{22} \mathrm{O}_{3}$ : C, 71.97; H, 8.86. Found: C, 71.70; H, 8.76\%. The ${ }^{1} \mathrm{H}$ NMR and ${ }^{13} \mathrm{C}$ NMR spectra were identical with those of $( \pm)-2$.

(3aS,6S,6aS,10aS)-3,3a,6,6a,7,8,9,10-Octahydro-6-hydroxy-4,7,7-trimethyl-1H-naphtho[1,8ac]furan-1-one [(+)-29]. In the same manner as described for the preparation of (-)-29, 31 gave (+)-29 (40.0 mg, 94\%) as colorless needles, $[\alpha]_{\mathrm{D}}^{30}+50.0^{\circ}\left(c 0.84 \mathrm{CHCl}_{3}\right)$, mp: $160.5-161.5{ }^{\circ} \mathrm{C}$. Anal. Calcd for $\mathrm{C}_{15} \mathrm{H}_{22} \mathrm{O}_{3}$ : C, 71.97; H, 8.86. Found: C, 72.08; H, 8.98\%. The IR, ${ }^{1} \mathrm{H} \mathrm{NMR},{ }^{13} \mathrm{C}$ NMR spectra were identical with those of (-)-29.

(1S,3aS,6S,6aS,10aS)-3,3a,6,6a,7,8,9,10-Octahydro-4,7,7-trimethyl-1H-naphtho[1,8a-c]furan1,6-diol [(-)-32]. In the same manner as described for the preparation of (+)-32, (+)-29 gave (-)$32(33.9 \mathrm{mg}, 99 \%)$ as colorless needles, $[\alpha]_{\mathrm{D}}^{29}-39.0^{\circ}\left(c\right.$ 1.05 $\left.\mathrm{CHCl}_{3}\right)$. HR-FAB-MS: $\mathrm{m} / \mathrm{z}$ calcd for $\mathrm{C}_{15} \mathrm{H}_{23} \mathrm{O}_{2}\left[\left(\mathrm{M}+\mathrm{H}^{+}\right)-\mathrm{H}_{2} \mathrm{O}\right] ; 2$ 235.1698: found; 235.1703. The IR, ${ }^{1} \mathrm{H}$ NMR, ${ }^{13} \mathrm{C}$ NMR spectra were identical with those of $(+)-32$

(1S,3aS,6aS,10aS)-3,3a,6,6a,7,8,9,10-Octahydro-1-hydroxy-4,7,7-trimethyl-1H-naphtho[1,8ac]furan-6-one; (-)-Fudecalone [(-)-2]. In the same manner as described for the preparation of (+)-2, (-)-32 gave (-)-Fudecalone [(-)-2, $24.6 \mathrm{mg}, 77 \%]$ as colorless needles, $[\alpha]_{\mathrm{D}}^{26}-23.6^{\circ}(c 0.53$ $\mathrm{MeOH}$ ). Anal. Calcd for $\mathrm{C}_{15} \mathrm{H}_{22} \mathrm{O}_{3}$ : C, 71.97; H, 8.86. Found: C, 71.84; H, 8.92\%.

\section{Acknowledgments}

We thank Prof. S. Omura and Dr. N. Tabata of the Kitasato Institute for the generous gift of the spectral data of natural fudecalone. We also thank Dr. K. Furihata of the University of Tokyo for measuring various NMR spectra. Thanks are due to Ms. H. Naito for elemental analysis. This work was supported in part by a Grant-in-Aid for Scientific Research from the Ministry of Education, Science, Sports, and Culture of Japan.

\section{References}

1. Tabata, N.; Tomoda, H.; Masuda, R.; Iwai, Y.; Omura, S. J. Antibiot. 1995, 48, 53.

2. Watanabe, H.; Furuuchi, T.; Yamaguchi, T.; Kitahara, T. Organic Lett. 1999, 1, 1079.

3. Watanabe, H.; Yamaguchi, T.; Furuuchi, T.; Kitahara, T. Tetrahedron Lett. 2001, 42, 917.

4. Sargent, M. V. J. Chem. Soc., Perkin Trans. 1 1987, 231.

5. Bu'Lock, J. D.; Smith, H. G. J. Chem. Soc. 1960, 502.

6. Biernacki, W.; Gdula, A. Synthesis 1979, 37.

7. Fairlie, J. C.; Hodgson, G. L.; Money, T. J. Chem. Soc., Perkin Trans. 1 1973, 2109.

8. Ohtani, I.; Kusumi, T.; Kashman, Y.; Kakisawa, H. J. Am. Chem. Soc. 1991, 113, 4092. 